\title{
India’s Gender Bias in Child Population, Female Education and Growing Prosperity: 1951-2011 with Projections to 2026*
}

\author{
D.P. Chaudhri, \\ Monash University, Australia
}

\author{
Raghbendra Jha, \\ Australian National University
}

\begin{abstract}
Using Census and NSS data this paper studies the evolution of Gender Bias (GB) in the age group 0-6 in India and its association with education and higher prosperity. GB is pervasive and has grown over time with higher prosperity and resultant demographic transition and enhanced education. The number of children in the age group 0-14 peaked in 2001 and has, since, been falling. Even as the under 5 mortality rate has fallen from 240.1 per thousand in the 1961 census to 65.6 in 2011, the total fertility rate (TFR) has experienced an equally sharp decline from 6.1 in 1961 to 2.6 in 2011. That large household size (associated with high fertility rates and low Monthly per capita expenditure (MPCE)) is linked with low GB comes as no surprise. However, with higher prosperity and lower TFR GB rises sharply. The percentage difference in GB in successive time periods fell from 0.3 in 1951 to 0.1 in 1961 but accelerated to 1.9 in 2011. GB is higher in the age group $0-4$ than in the $0-6$ group. GB has actually improved for the age group 10-14 but this fact is irrelevant for the evolution of GB in children since children in that age group will soon be adults. Hence, the outlook for GB in the age group 0-6 appears bleak at least until 2026. The paper also demonstrates that there are wide variations in GB across various states, even districts, of India. In 2011 child population is still high in the EAG states whereas the growth of child population has come down substantially in some states, particularly some southern states and Himachal Pradesh. At the district level we discover that the education of girls is an important determinant of GB. At the household level both improved education of females in the age group 15-49 and higher prosperity lead to worsening of GB. However, at high values of the interaction of these two variables there could be a turnaround in the trend of worsening GB. At present trends, however, this is unlikely to happen at least until 2026. More positive outcomes require social engineering through multidimentional, orchestrated policies, especially in relation to enhanced prosperity and education of women in the child bearing age group. Improvements in GB are discernable in some districts, states and households. In 55 districts GB declined and proportion of girls attending schools increased. Kerala and Tamil Nadu did not have any worsening of GB while GB declined in Himachal Pradesh. Finally, prosperity improved GB among Scheduled Castes, Scheduled Tribes and Muslims, and households having women in child bearing age group with graduate degrees.
\end{abstract}

Keywords: Gender Bias, Census, National Sample Survey, Demographic Transition, India JEL Classification Code: J16, N35, O15, O53

All correspondence to:

Prof. Raghbendra Jha,

Australia South Asia Research Centre,

Arndt-Corden Department of Economics,

Crawford School of Economics \& Government

College of Asia \& the Pacific,

Australian National University,

Canberra, ACT 0200, Australia

Phone: + 6126125 2683, Fax: +61 261250443

Email: r.jha@anu.edu.au

\footnotetext{
${ }^{*}$ We are grateful to Hai Anh La for competent research assistance. The usual disclaimer applies.
} 


\section{Introduction and Motivation: Pervasive Son Preference in India and China}

India and China's re-emergence as economic powerhouses has naturally attracted serious attention. Worsening economic inequality has been noted and attributed to non-inclusive economic growth. An element of worsening social inequality, namely rising gender bias (henceforth GB) in child population, has also become evident. This phenomenon remains under researched and there is an urgent need to understand its changing intensity, extent, diversity and serious long-term implications as a soft underbelly of economic development.

The UN Convention on Rights of the Child (1989) requires that state parties ensure that children are nurtured. ${ }^{1}$ India and China, being signatories to this convention, have an international obligation to ensure that GB in their child population is reversed. That it is in their economic and social interest to do so, in view of their rising global importance, is obvious. India and China, as mainly patriarchical societies, developed a son preference for economic and cultural reasons. Religious and social customs reinforced it over a very long time. The dependence on sons in old age created laws of inheritance (changed in both countries in 1950s) when these were mainly agrarian societies, virtually till 1960s. High total fertility rates (TFR) at over six per thousand in both these countries masked the son preference to some extent. Number of children per family at 4 to 6 created a near gender balance with a slight tilt in favour of boys partly due to neglect of girls in early years of childhood and also due to infanticide of girls. ${ }^{2}$ Number of girls at 952 per thousand boys or number of boys at 105 per 100 girls was considered normal in India and China, respectively, during the 1950s.

The very different attempts at population control in India and China and improvements in child mortality rates (World Bank, 2011) as well as rising prosperity resulted in sharp drop in TFR in both these countries. In 2005 China's TFR stood at 1.9 and India's was 2.7 in 2011. China imposed a one child family norm in 1980s whereas the prosperous in India, about one fourth to one third of population, achieved it by choice. ${ }^{3}$ The rising prosperity and sharply declining TFR met new reproductive technologies of medical sciences resulting in worsening GB among children in India and China. Comparing GB among children in age group 0-4 years, similarities in India and China are surprising and have been noted by demographers and specialists in this field. For this age group number of girls per thousand boys in 2005 was 833 in China and India will be fast approaching it. Indeed the prosperous in India are already nearing it. The conventional son preference, based on number of girls per thousand boys, in the absence of demographic transition or prosperity has been around 952. Policymakers in India need to take serious multi dimensional corrective steps to avoid further deterioration in the child gender ratio. ${ }^{4}$

This paper, in an attempt to fill a gap, provides a perspective on and prognosis for India's worsening GB in child population (0-14). This can be subdivided into four groups: 0-4, 5-9, 10-14 and the new conventional 0-6. In this paper we concentrate on GB in India in the age group 0-6 but comment occasionally on GB in other age groups as well. The paper is divided into eight sections. Section II is devoted to India's worsening GB in child population from

\footnotetext{
${ }^{1}$ See UNICEF (1989), UN Convention on Rights of The Child, UNDP (2010), and also Government of India (2009) and Weiner (1991) on India.

2 There is a vast literature on this issue. Dasgupta and Li (1999) \& Li (2007) summarize it for these two countries.

${ }^{3}$ See Chaudhri \& Jha (2011a) on number of children in families by expenditure/income groups.

${ }^{4}$ See Chaudhri \& Jha (2011b), Premi (2001) for India, Johansson and Nygren (1991), Zeng et al. (1993) and Li (2007) for China.
} 
1951 to 2011 and its potential to persist till 2026 and beyond. In section III, we analyse GB in child population across states of India for 1993-94 and 2004-05 from the National Sample Survey (NSS) data and also data from the 1991, 2001 and 2011 censuses. Section IV is devoted to an analysis of District data from 1991 and 2001 censuses. In section V, we examine GB across household consumption, social groups and by female education at the all India level for 1993-94 and 2004-05. Section VI is devoted to a search for regularities and causal chain in the analysis of district level data for 1991 \& 2001, Section VII deals with GB and its relation with female education among different expenditure groups and their interactions. Section VIII provides conclusions and implications for corrective social policies.

\section{Gender Bias in India's Child Population}

India's child population (0-14) increased from 134 million in 1951 to a peak of 365 million in 2001. In 2011 it is estimated at 347 million and is expected to decline to 327 million in 2026 (Figure1).

\section{Figure 1:}

\section{Child population (0-14 years with sub-groups) of India by gender and age groups in 1951-2001 with projections to 2026}

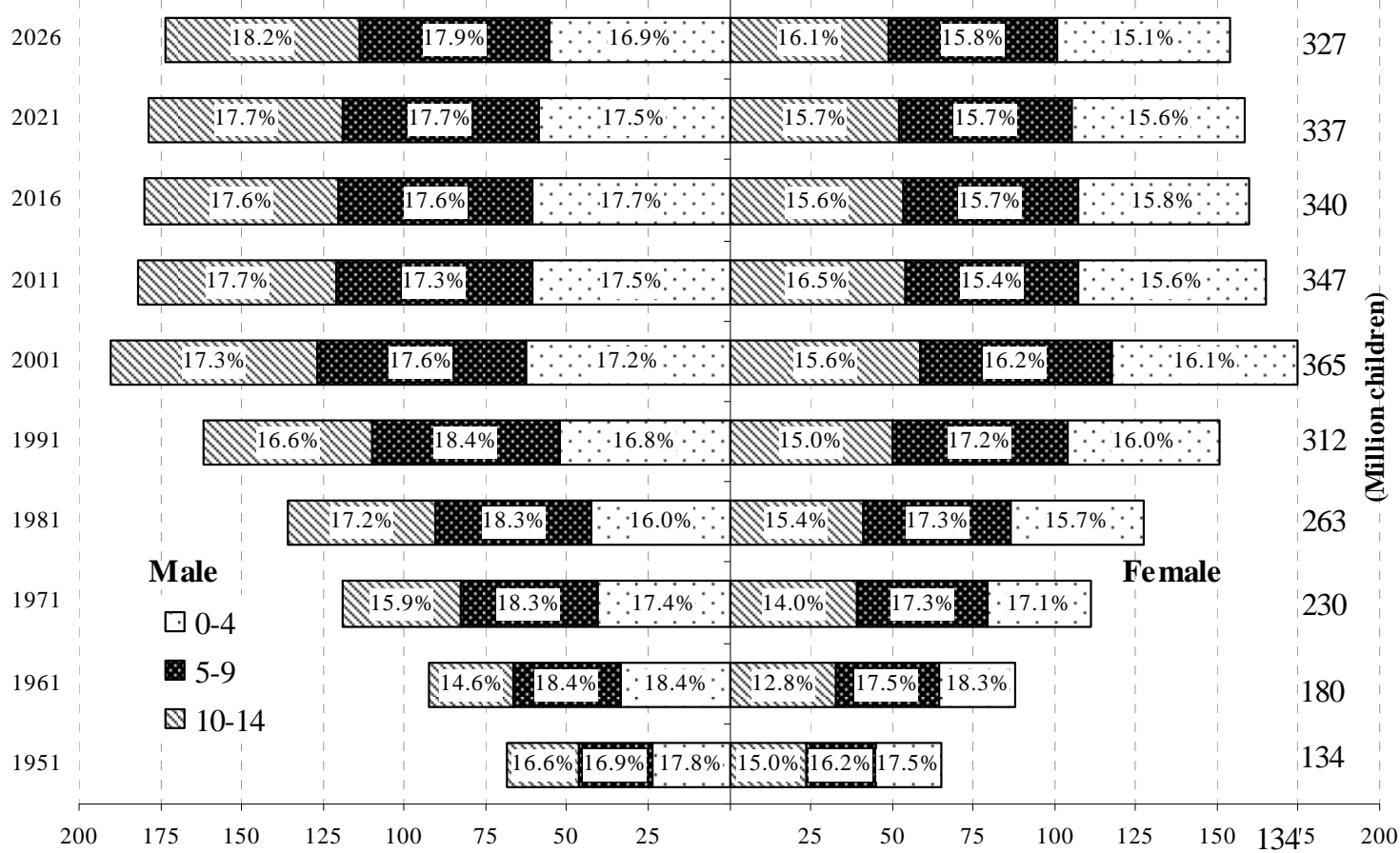

Sources: 1. Chaudhri, D.P. (1996), A Dynamic Profile of Child Labour in India 1951-91,CLASP,ILO New Delhi, June 1996

2. Census of India 2001, Population Tables and Population Projections for India and States 2001-2026

Gender composition during this period changed against girls. In 1951, 17.8\% of child population (0-14) consisted of boys and $17.5 \%$ girls in the age group $0-4$, yielding a GB of $0.3 \%$. In 1961 this declined to $0.1 \%$ because of increasing TFR (from 6.1 per thousand to 6.5 per thousand). This rise in TFR can be ascribed partly to the post-Second World War fertility surge and partly to public health efforts towards maternal health, particularly at childbirth. The GB in 1991 increased to $0.8 \%$ and stood at $1.1 \%$ in 2001 . It is projected to be at $1.9 \%$ in 2011 and expected to decline marginally in 2026 to $1.8 \%$ as can be noted from figures 1 and 2. 
Figure 2:

Gender Bias, percent in child population (0-4) and total fertility rates in India 1951-2011

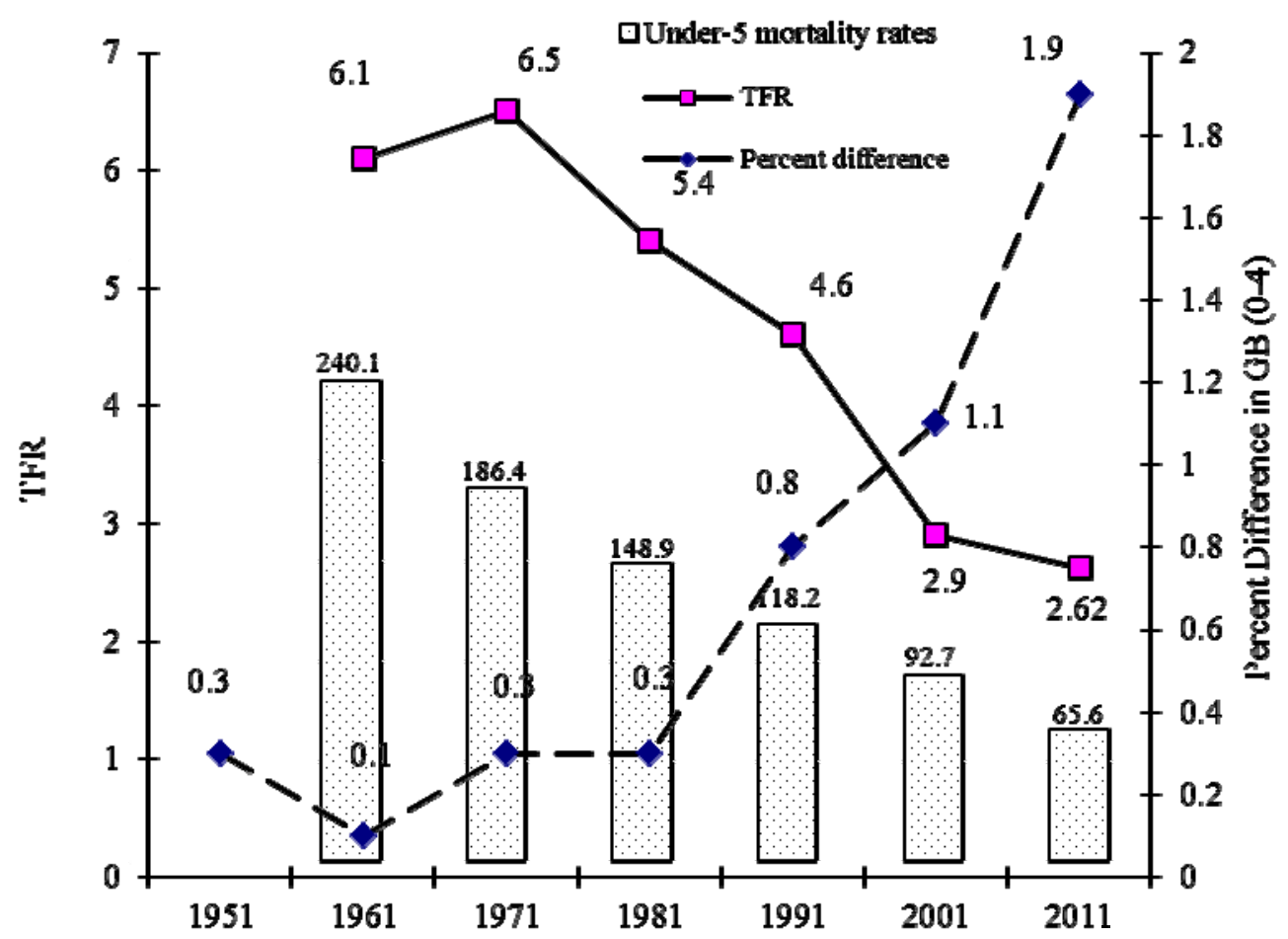

Sources: 1. Census of India 1961, 1971, 1981, 1991, 2001 and 2011

2. World Bank Database

The recently reported census 2011 results on GB in 0-6 age group (the data for other agegroups has not been released yet), pointing out a decline in number of girls per 1000 boys from 927 to 914 between 2001 and 2011, invoked huge response in the media. Chaudhri and Jha (2011b) commenting on it pointed out that prosperity in India has met new medical reproductive technologies to give us this result. This should hardly be surprising. They concluded that there is a U-shaped curve representing number of girls per thousand boys that will eventually emerge in India. The duration and depth of the U curve will depend upon orchestrated public policies or their absence. ${ }^{5}$ Had the census authorities reported the GB for either the age group $0-4$ or 5-9, this would have come out to be much worse, as can be noticed from figure 3 . There is a rich literature discussing proximate causes like son preference resulting in selective abortions, differential infant and child mortality rates, infanticide of girls and unequal access to nutrition and health in early years. The inference that faster economic development, education, and knowledge do not necessarily ameliorate son preference seems to be unfolding in modern India with rising prosperity. ${ }^{6}$

GB in age-group 10-14 in percentage terms in 1951 was $1.6 \%$, it increased marginally to $1.7 \%$ in 2001 , over a 50 year period and is projected to increase to 2.1 by 2026 . For the age group 5-9, it increased from $0.7 \%$ in 1951 to $1.4 \%$ in 2001 and is expected to rise to $2.1 \%$ by 2026. The details are in figures $1,2,3$, and 4.

\footnotetext{
${ }^{5}$ See Chaudhri \& Jha (2011a), NUEPA (2011) on Education, Rustogi et al. (2008), among many others.

${ }^{6}$ See Chaudhuri and Jha (2011b).
} 
Figure 3:

Child sex ratio 0-14 years: 1951-2011

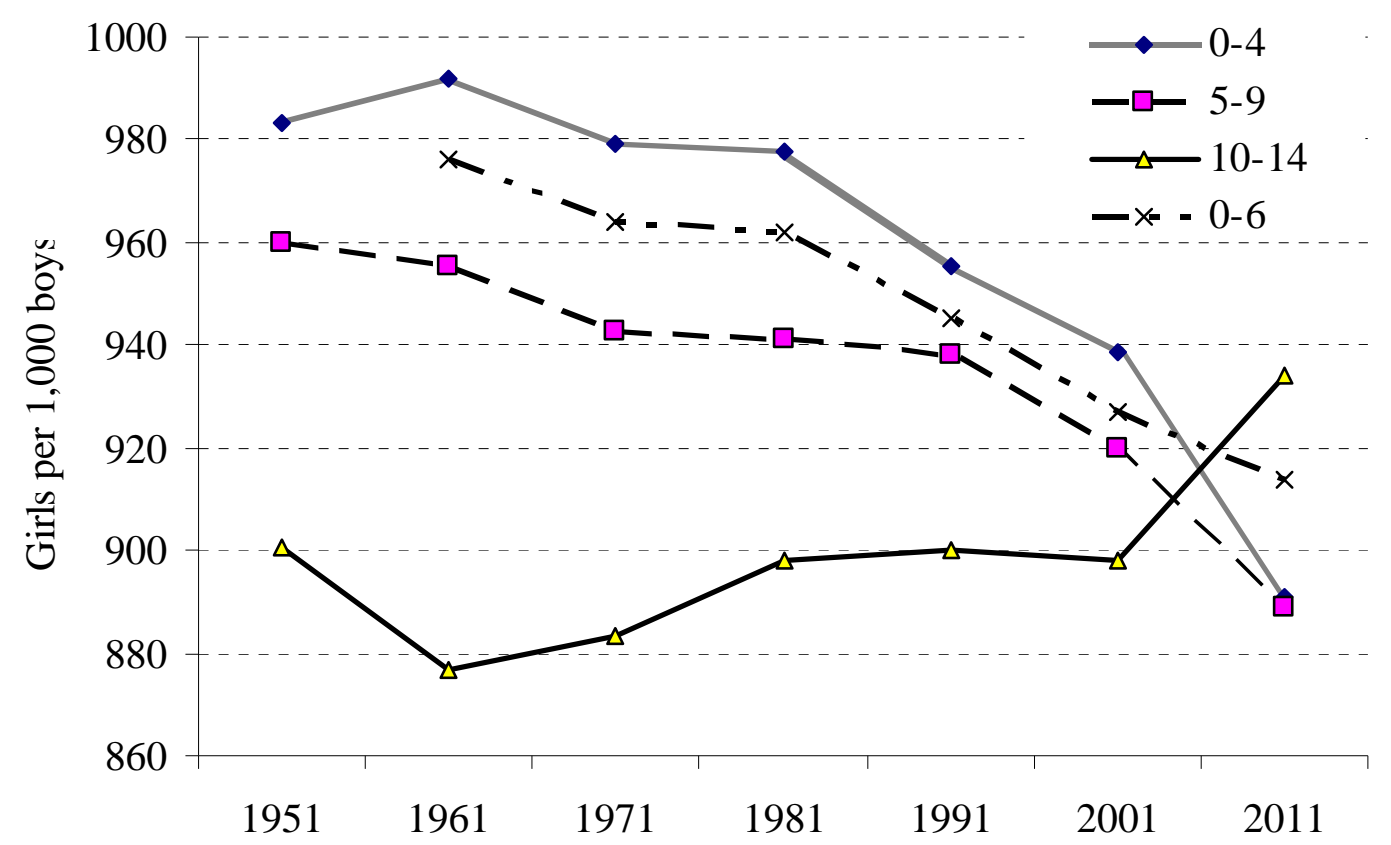

Sources: 1. Chaudhri, D.P. (1996), A Dynamic Profile of Child Labour in India 1951-91, CLASP, ILO New Delhi, June 1996

2. Census of India 2001, Population Tables and Population Projections for India and States 2001-2026

3. Census of India 2011 (for $0-6$ age group)

Figure 4:

Child sex ratio 0-14 years projections to 2026

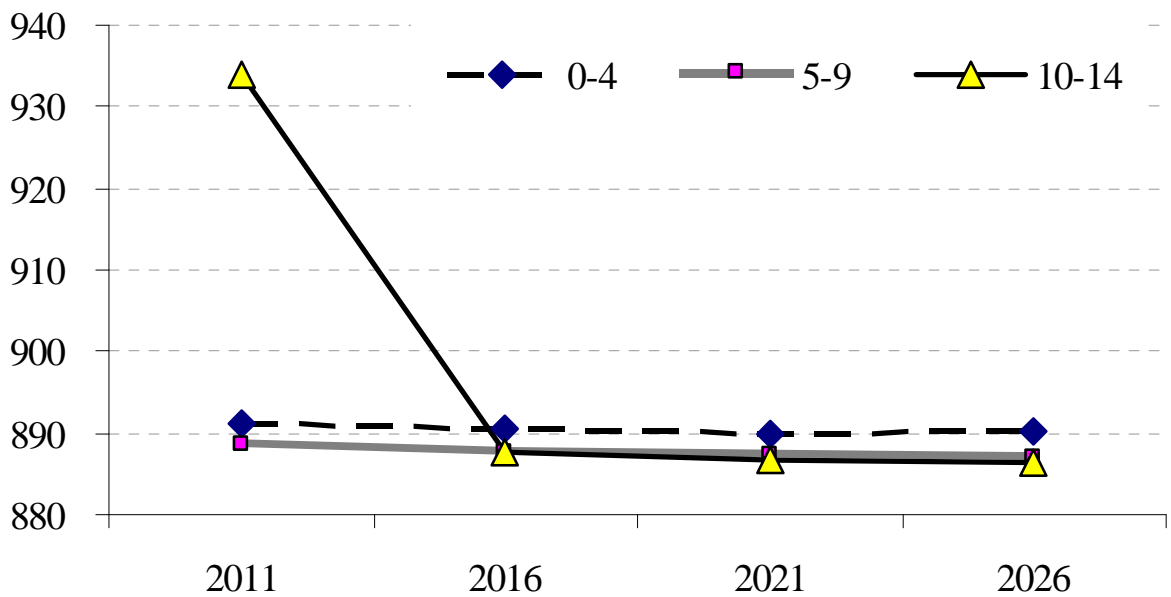

Sources: 1. Chaudhri, D.P. (1996), A Dynamic Profile of Child Labour in India 1951-91, CLASP, ILO New Delhi, June 1996

2. Census of India 2001, Population Tables and Population Projections for India and States 2001-2026

3. Census of India 2011 (for $0-6$ age group) 
Thus we find that the decline in TFR and under five mortality rates provide demographic transition but GB among children gets worse due to persisting son preference and relative neglect of girl child in nurturing during early years and also in schooling. A large, diverse and complex country like India is bound to have important variations across states, regions and income groups. We explore this question at the state level in the next section.

\section{Gender Bias Across States of India}

We have summarised information on GB among children less than six years of age for different states of India for the census year 2011 (Registrar General of India, 2011) and reported this in Figure 5 and also Appendix Table A1. The states are ordered in two groups, one belonging to the Empowered Action Group ${ }^{7}$ (EAG) states that are considered to be socially and economically lagging with the rest being labeled ROS (rest of states). A number of interesting points bringing out the diversity across India are noteworthy. Child (0-6) GB in EAG states is not substantially different from the all India averages. This is because these states have over half of child population under six years of age in 2011. The share of these states has been rising as can be seen from Figure 5 and also Appendix Table A1, by comparing row one and two.

Figure 5:

\section{Child population (0-6 years) (unit: thousand children) in 2011}

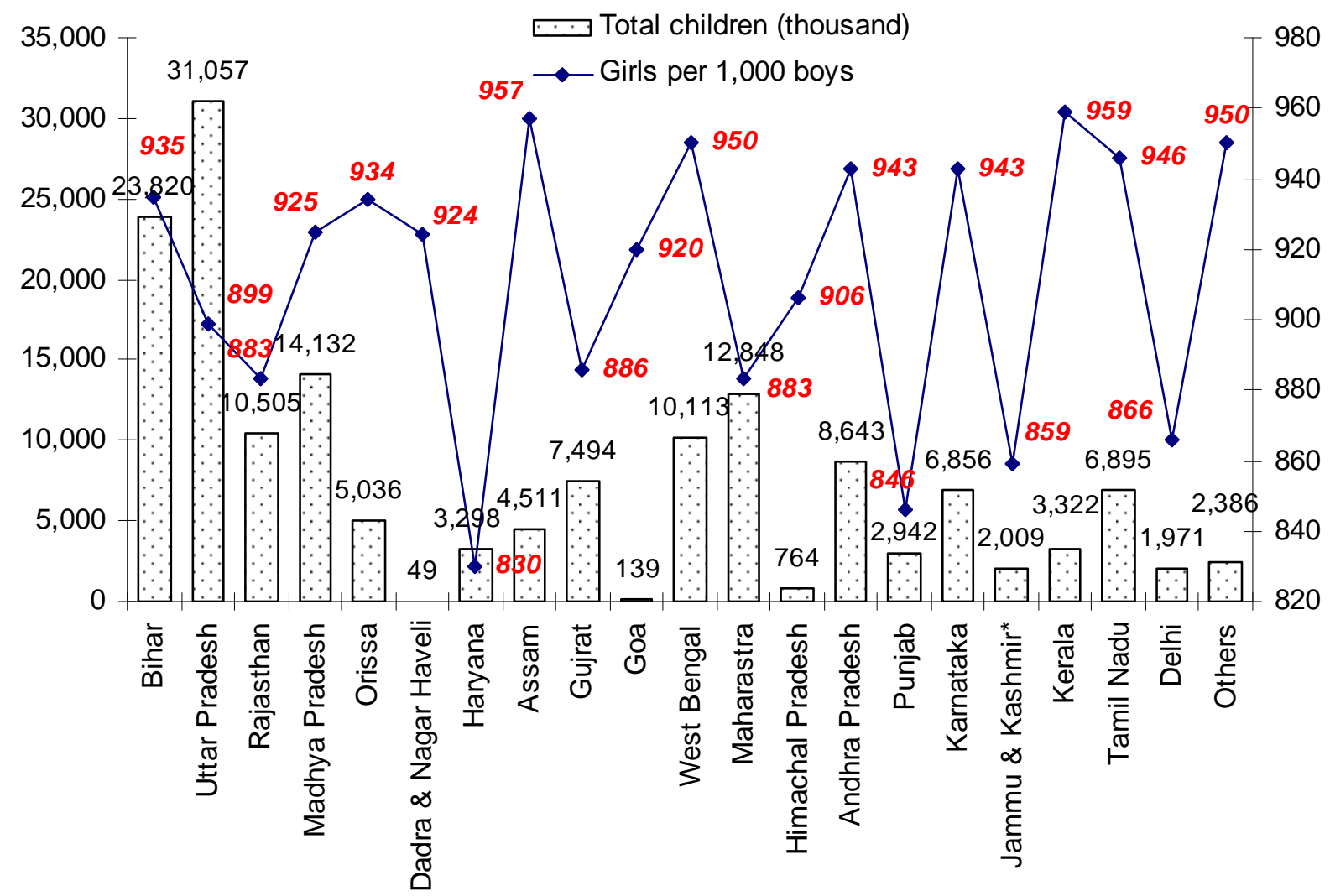

Notes: (*) Gender bias: females per 1,000 males; (**) Excludes Jammu \& Kashmir where 1991 census was not held.

Ranking according to reducing children proportion of the population Sources: Census 2011

\footnotetext{
${ }^{7}$ EAG States include Rajasthan, UP, Uttarakhand, Bihar, Jharkhand, MP, Chhattisgarh and Orissa
} 
Child GB in ROS for each of the census years from 1991 (Registrar General of India, 1991) to 2011 is lower compared with the EAG states or the all India average. Change in GB during these 20 years has been very uneven across states in these two groups. In Kerala the number of girls per thousand boys in 1991 was 958, rose to 960 in 2001 (Registrar General of India, 2001) and declined to 959 in 2011, suggesting a virtually unchanged situation. Similarly in Tamil Nadu, the number of girls per thousand boys was 948 and 1991, 942 in 2001 and 946 in 2011. Thus, there is not much change in Tamil Nadu either. In Himachal Pradesh in 1991 number of girls per 100 boys was 951; this number declined to 896 in 2001 and increased to 906 in 2011. Himachal Pradesh provides a sort of U-shaped curve in GB that we expect with appropriate policies. A major EAG state, Uttar Pradesh, had 928 girls per thousand boys in 1991. The number declined to 915 in 2001 and has further declined to 899 in 2011. This indicates a sharp decline from 928 to 899 in 20 years. As noted above, pace of demographic transition is one component driving this change. Other economic, social and cultural factors seem to be playing an important part. The demographic transition in Kerala had occurred before 1991. The stability there is an important key to our understanding of worsening GB in other states of India.

Figure 6:

Gender bias among children (0-6 years) in poverty and non-poor groups in India in 2004-05

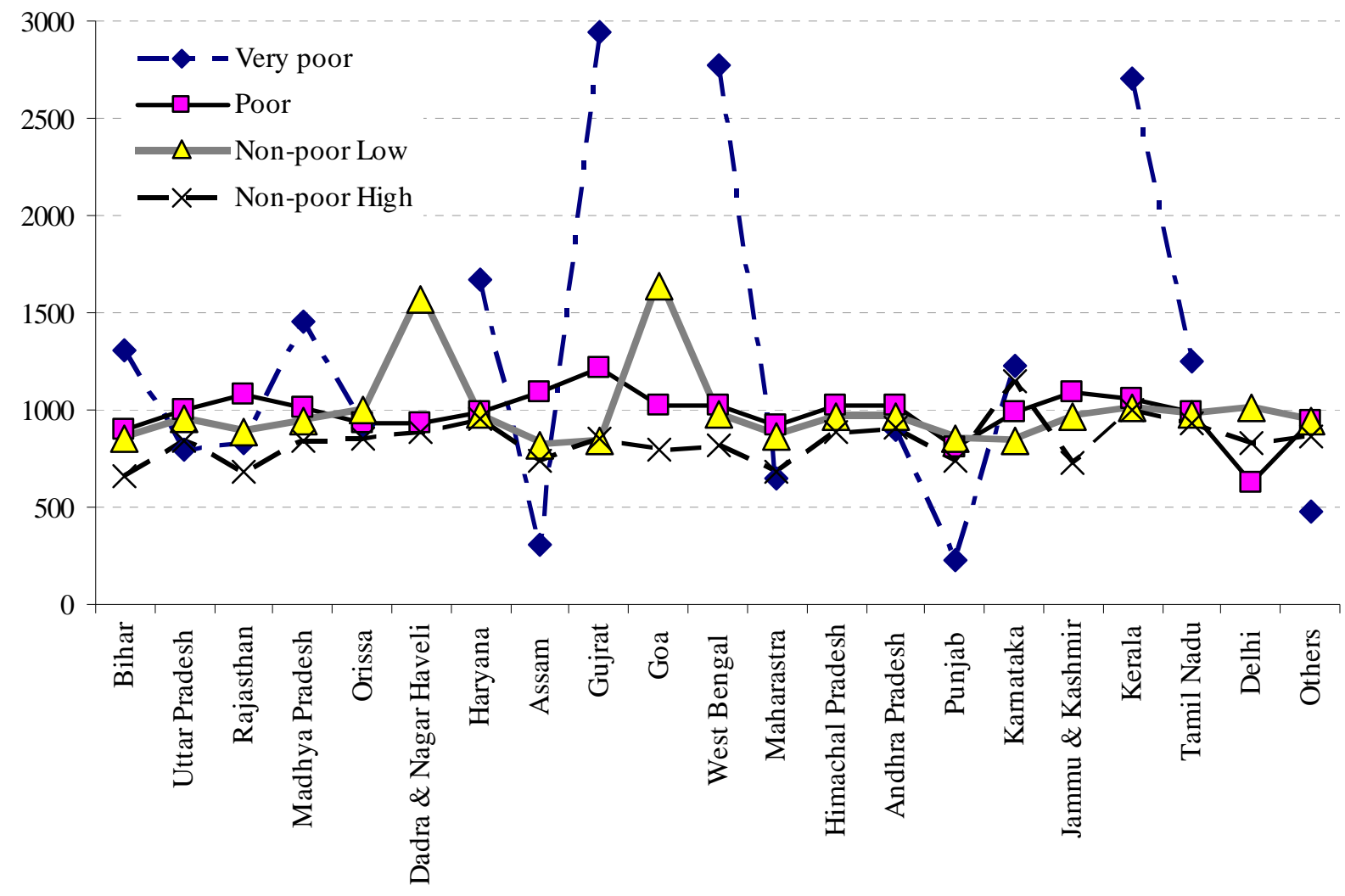

Sources: 1. Computed from NSS $61^{\text {st }}$

2. Chaudhri \& Jha, 'Child Poverty and Elementary Education in India', ASARC Working Paper 2011/04.

Notes: Ranking according to reducing children proportion of the population. 
To explore the link between poverty status and GB we present household data on child (0-6) GB from NSS 2004-05 survey in Figure 6. The households are divided into four consumer expenditure groups. Group of ultra-poor consists of those whose expenditure is less than half the absolute poverty line. The poor households are those whose expenditure is below the poverty line but above that of the ultra-poor. The non-poor low group consists of those households whose expenditure is above the poverty line but less than twice the expenditure at the poverty line. The non-poor high consumption group consists of those whose expenditure is more than double the expenditure level at the poverty line. Chaudhri and Jha (2011a), using this classification, have demonstrated that the poor and ultra-poor have larger number of children in each household compared with the non-poor. The number of children in an average family of the non-poor high consumption at 0.9 is the lowest. Thus, interestingly, whereas China achieved one child family norm by compulsion the Indian non-poor high consumption group achieved this through choice. While interpreting the data presented in table 2, the fact of statistically different number of children in each of the four subgroups, need to be kept in mind.

Diversity across India and differences between EAG and ROS, noted above, come into sharper focus when the intensity of poverty is considered in an analysis of GB among children. First, we note that GB is lowest among the poor and ultra-poor and highest among the non-poor high consumption groups. In view of the fact that this group has less than one child per family, the effect of sharp demographic transition and prosperity becomes evident. The household data analysis unambiguously indicates that the drivers of worsening GB among children are to be found among the prosperous. Revealed boy preference is openly visible.

Major differences across states are also noticeable although the monotonic decline in number of girls per thousand boys among four groups persists everywhere. In Kerala, we find that in 2004-05 the number of girls per thousand boys exceeded 1000 suggesting a GB in favour of girls. The average number of girls per thousand boys was 1024 while among the poor it was 1060 and among the non-poor high consumption group it was 1001. The numbers in Tamil Nadu and Himachal Pradesh follow ah monotonic pattern with the number of girls per thousand boys among the rich at 937 and 887 respectively, much lower than among the poor. By contrast, in Uttar Pradesh, we find that number of girls per thousand boys on average was 960, among the poor 996, non-poor low 954 and non-poor high 839. Sharp differences are noticeable across groups. These differences are statistically significant at $1 \%$.The numbers for Rajasthan, Madhya Pradesh and Orissa have even sharper differences as can be seen in Figure 6 and Appendix TableA2.

In view of very small number of ultra-poor households in many prosperous states, the GB averages are unstable for this group. Thus increasing prosperity alone is likely make the GB even worse as noted above. In the next section we present analysis of district level data along with education of girls to examine this question.

\section{Gender Bias Across Districts}

A state is a large unit in population terms and masks diversity that exists at the lower levels of aggregation. Administrative districts satisfy this requirement since every state is divided into a number of districts. For 1991 data for 334 Indian districts were available. Due to population growth and administrative convenience a number of these were bifurcated resulting in the number of districts rising to 594 in 2001 . We divide the districts into four 
groups according to number of girls per thousand boys (0-6 years) and proportion of girls (514 years) attending school by the criteria of all India average for each category as depicted in Figures 7 and 8. Quadrant I represents districts with above average average number of girls per 1000 boys but below-average proportion of girls attending schools and quadrant IV presenting its reverse. The best outcome from the perspective of GB and schooling is in quadrant III where the number of girls per thousand boys is higher than the national average and also the proportion of girls in schools. Worst case is represented in quadrant II, where GB is higher and also proportion of girls in school is below the national average. For Census of India 1991 and 2001 we analysed the district data and a summary of the results is presented in figures 7 and 8.

Figure 7:

GB (girls aged 0-6 per 1,000 boys) v.s. girl student share during 1991-2001

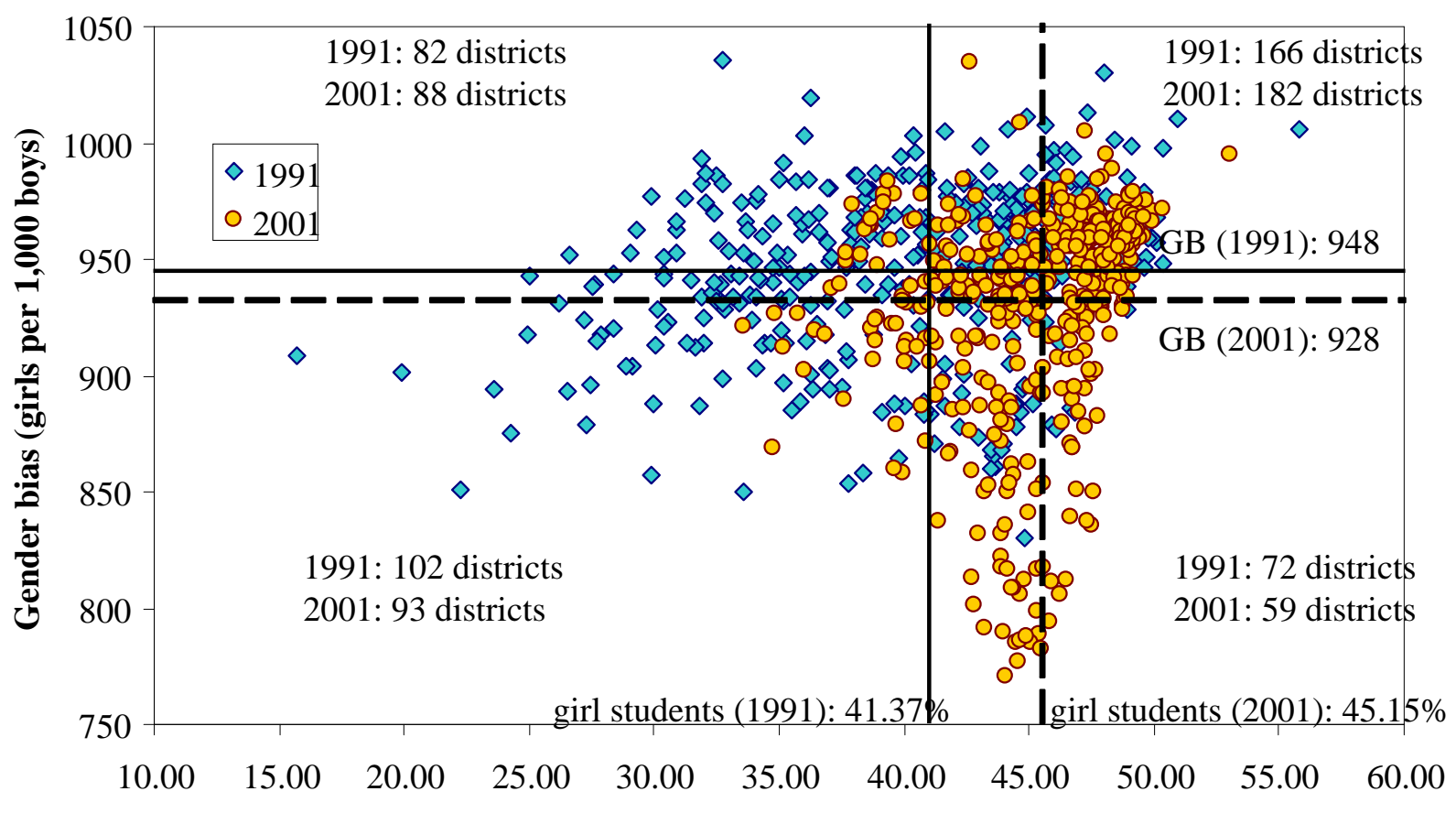

Proportion of girls (5-14) in schools (\%)

Source: Calculated from Cansus of India, 1991, 2001

In 1991 there were 82 districts in quadrant I, the number of girls per thousand boys was higher than the national average but proportion of girls attending schools was lower than the national average in these districts. The number of districts in this group increased to 88 in 2001. The worst-case scenario represented in quadrant II had 93 districts in 1991 and the number increased to102 districts in 2001. These districts both the proportion of girls per thousand boys and the proportion of girls attending school were lower than the respective national averages. In quadrant IV the number of districts, where the proportion of girls attending school was higher than the national average but the number of girls per thousand boys was lower than the average national average, was 72. Number of districts in this category declined to 59 in 2001. The best case scenario presented in quadrant III where the proportion of girls in schools as well as number of girls per thousand boys was higher than the national average, had 166 districts in 1991 and the number increased to 182 districts in 2001. 
Figure 8:

Change in GB (girls aged 0-6 per 1,000 boys)

v.s. change in girl student share during 1991-2001

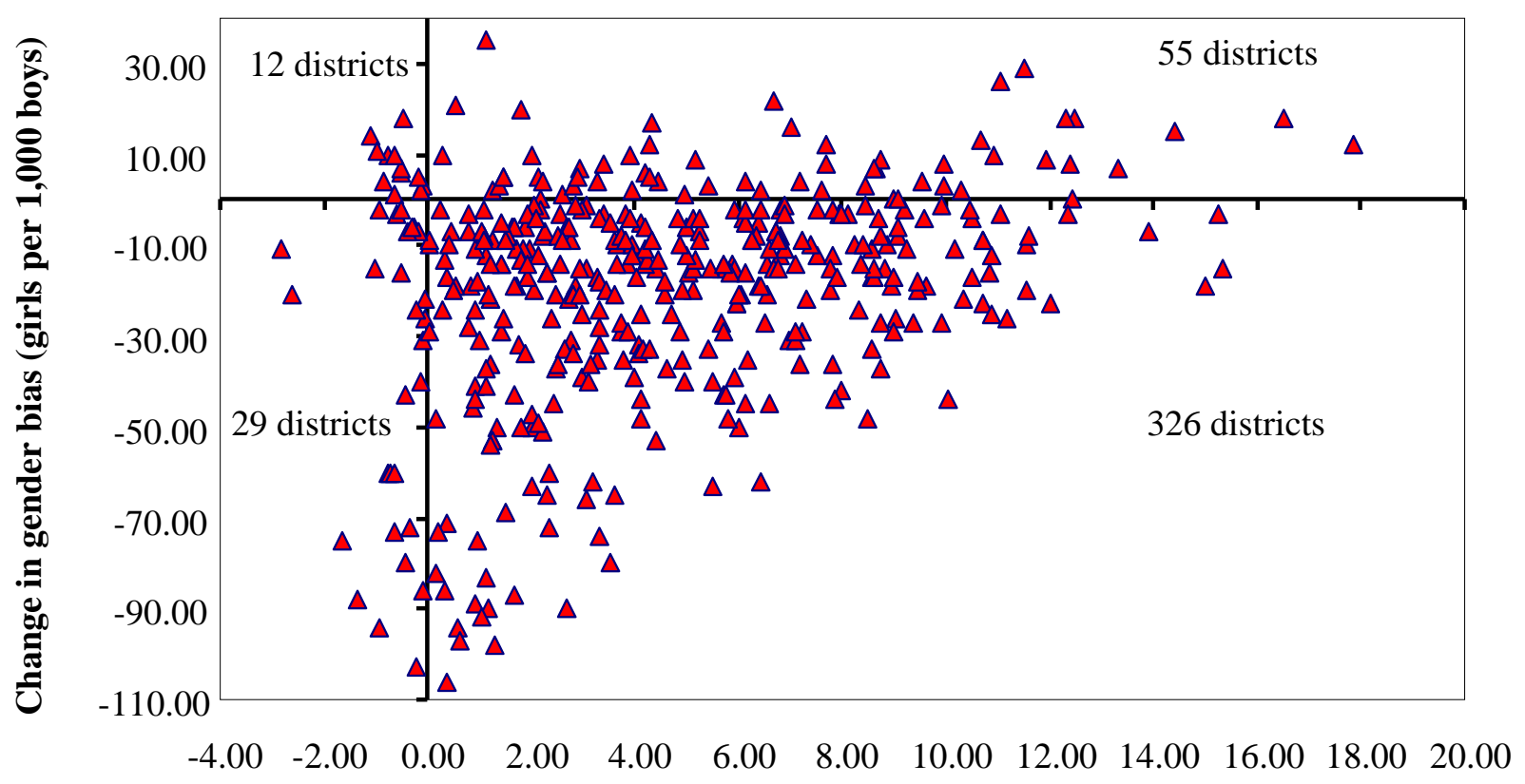

Change in proportion of girls (5-14) in schools (\%)

Source: Calculated from Census of India 1991, 2001

The national average of GB in 1991 was 948 girls per thousand boys but this dropped to 928 in 2001. A drop of 20 in one decade is indicative of sharp demographic transition. Actual names of the districts in each of these four quadrants are presented in appendix table A3. It is worth noting that no single state or group of states dominate any of these four quadrants, suggesting huge diversity. Using a nonparametric chi-square test, we found that for 1991 as well as 2001 districts in each of these four categories were statistically different. The results are reported in appendix tables A3, A4 and A5 last row.

During the decade of the 1990s, a sharp demographic transition across a large part of India and public effort at increasing the proportion of children in school occurred in the backdrop of traditional persisting boy preference. We summarise the change between 1991 and 2001 in GB, namely number of girls per thousand boys and change in percentage of girls attending school in figure 7. On the $\mathrm{x}$-axis the change in proportion of girls is in percentage terms and on the $\mathrm{Y}$ axis the change in number of girls per thousand boys is an absolute numbers. We know from figure 6 that this had decline from 948 two 928 during this decade. Some very interesting, but startling patterns emerge. First, the number of districts in the third quadrant, experienced a reduction in GB and also the proportion of girls attending schools increased to, is 55. Out of a total of 594, 55 is a small number. However, in terms of child population this does represent about 5 million children, which is not a small number. The number of districts where both the GB and the proportion of girls attending schools declined is 12. Surprisingly, most of these districts are in Kerala and Tamil Nadu as can be noted from appendix table A5. In 29 districts the proportion of girls attending school declined as also the number of girls per thousand boys. In most of India, (326 districts) the proportion of girls attending schools 
improved but the number of girls per thousand boys declined. In figure 8 we have shown that proportion of girls attending schools increased from $41.37 \%$ in 1991 to $45.15 \%$ in 2001.

Notice that schooling worsened in 41(12+29) districts of India despite public effort. In terms of number of girls per thousand boys the decline shown in the fourth quadrant is a number. In most districts in this quadrant the decline has been 10 to 20 per thousand.

The conclusion that all India and state averages mask a number of diverse patterns in various districts of India is unavoidable. We have a situation where schooling and proportion of girls are increasing in only 55 districts. Further, the latter is worse in 29 districts. For most of India rising proportion of girls in school is accompanied by a worsening GB by about 10 to 20 points per thousand.

To examine GB at the household level among educated and uneducated mothers we work with household data from NSS in the next section.

\section{Child Poverty, Women's Education and Social Groups}

We compared GB computed from household data from NSS sources and the Census of India. The results are reported in table 1. We also computed GB among households with different intensity of poverty and prosperity in four groups as described above. Within each of these four consumer groups we divided the households into four social classes. These are households belonging to scheduled castes, scheduled tribes, Muslims and others. The GB in each of these four consumption sub-groups and four social sub-groups within each of the four consumption sub-groups during 1993-94 and 2004-05 and change over the decade is reported in Table 1.

Comparing GB among children (0-6) in two Censuses, 2001 and 2011, we notice an increase in GB of 13 per 1000, with the number of girls declining from 927 to 914 . The decline was larger in EAG states at 17 points compared with the ROS at 10 points. Changing GB computed from the household data shows an improvement in EAG states of 19 points and a worsening in ROS by five points. The periods being compared are different and also, although NSS is a large representative sample, it is a sample. The effects of demographic transition have been greater between 2001 and 2011 compared with the earlier decade.

The comparison of four consumption groups provides a rich detail. Among the very poor the GB declined by 28 points. In this category the GB declined in SC, ST and Muslim households whereas others showed a worsening of GB, providing an overall average improvement by 28. Among the poor also GB declined by 32 points with a larger decline among SC and others and worsening among the ST, while remaining roughly unchanged among Muslims. Among the non-poor and low consumption group the overall improvement in GB was 7 points; among SC the improvement was 70 points, and among others it was 5 points whereas it worsened among ST and Muslims. The most interesting contrast comes from the non-poor high consumption group. Comparing different figures within the column we find that GB increases monotonically from the Ultra poor to the non-poor low and is highest among the non-poor high consumption group. The GB among high consumption group between the two periods worsened from 843 girls per thousand to 836 per thousand. Across social groups, GB improved among SC, ST and Muslims, while it worsened among the others category by 30 points giving us an overall average of worsening by seven points. 
Table 1:

Gender bias in child population (0-6), social groups and child poverty in India 1993-94 to 2011

\begin{tabular}{|c|c|c|c|c|c|c|}
\hline 1 & 2 & 3 & 4 & 5 & 6 & 7 \\
\hline & NSS HH & Data & & Census & Data & \\
\hline $\begin{array}{c}\text { Gender bias } \\
\text { (females per 1,000 males) }\end{array}$ & 1993-94 & 2004-05 & Change & 2001 & 2011 & Change \\
\hline Total & 923 & 930 & 7 & 927 & 914 & -13 \\
\hline EAG & 914 & 933 & 19 & 930 & 913 & -17 \\
\hline ROS & 932 & 926 & -5 & 925 & 915 & -10 \\
\hline $\begin{array}{l}\text { Among Very Poor(MPCE less than } \\
\text { Half of Poverty Line) }\end{array}$ & 989 & 1,016 & 28 & & & \\
\hline - Scheduled Caste & 946 & 1,160 & 214 & & & \\
\hline - Scheduled Tribe & 1,067 & 1,074 & 7 & & & \\
\hline - Muslim & 1,022 & 845 & -178 & & & \\
\hline - Others & 977 & 951 & -27 & & & \\
\hline $\begin{array}{l}\text { Among Poor(MPCE below Poverty } \\
\text { Line but above half of it) }\end{array}$ & 949 & 981 & 32 & & & \\
\hline - Scheduled Caste & 956 & 1,031 & 76 & & & \\
\hline - Scheduled Tribe & 998 & 927 & -71 & & & \\
\hline - Muslim & 939 & 937 & -2 & & & \\
\hline - Others & 937 & 985 & 48 & & & \\
\hline $\begin{array}{l}\text { Among Non-Poor Low(MPCE Above } \\
\text { Poverty Line, less than double) }\end{array}$ & 912 & 919 & 7 & & & \\
\hline - Scheduled Caste & 919 & 989 & 70 & & & \\
\hline - Scheduled Tribe & 960 & 892 & -69 & & & \\
\hline - Muslim & 927 & 888 & -39 & & & \\
\hline - Others & 902 & 907 & 5 & & & \\
\hline $\begin{array}{l}\text { Among Non-Poor High(MPCE More } \\
\text { than double of Poverty line) }\end{array}$ & 843 & 836 & -7 & & & \\
\hline - Scheduled Caste & 856 & 917 & 62 & & & \\
\hline - Scheduled Tribe & 760 & 1,026 & 266 & & & \\
\hline - Muslim & 846 & 859 & 13 & & & \\
\hline - Others & 845 & 815 & -30 & & & \\
\hline
\end{tabular}

Note: EAG States include Rajasthan, UP, Uttarakhand, Bihar, Jharkhand, MP, Chhattisgarh and Orissa (Census of India 2011); MPCE = monthly per capita expenditure

Source: 1. Computed from NSS 50th and NSS 61st

2. Census of India 2001, Census of India 2011

3. Chaudhri DP \& R. Jha, 'Child Poverty and Elementary Education in India', ASARC Working Paper 2011/04

Three inferences can be made. First, overtime GB in child population has been worsening, with the deterioration having increased in the last decade. Second, GB is highest among the non-poor high consumption group and lowest among ultra poor and poor households.

Prosperity seems to be detrimental to gender equality among children. Third, within the social groups observed patterns in GB is mixed. Among the non-poor high consumption group, GB is worst among others category - a majority in India. It declined among SC, ST and Muslim households. In the other three consumption groups the change in GB among social subgroups switches sign between poor and non-poor low consumption groups. 
With a view to examining the role of women's education in GB we divide the entire household data sets into four groups according to education of the females in the reproductive age-group. These women's groups are illiterate, with middle school education, with higher secondary education and graduates. The results are reported in table 2 .

Table 2: Gender bias (0-6 years) among households with females aged 15 to 49 by education in 1993-94 and 2004-05

\begin{tabular}{clcccc}
\hline \multirow{2}{*}{ Year } & & \multicolumn{4}{c}{ HHs with females aged 15 to 49 } \\
\cline { 3 - 6 } & & Hliterate & Middle schools & High secondary & Graduates \\
\hline \multirow{2}{*}{$2004-05$} & Average household size & 5.01 & 5.26 & 5.10 & 5.05 \\
& Girls per 1,000 boys & 954 & 910 & 882 & 891 \\
& Observations & 33,891 & 56,315 & 9,833 & 7,808 \\
\cline { 2 - 6 } $1993-94$ & Average household size & 5.07 & 5.43 & 5.43 & 5.04 \\
& Girls per 1,000 boys & 936 & 912 & 834 & 814 \\
& Observations & 44,406 & 43,453 & 5,585 & 5,780 \\
\hline
\end{tabular}

Sources: 1. Computed from NSS 61st Round for 2004-05 and NSS 50th Round for 1993-94

2. Chaudhri \& Jha, 'Child Poverty and Elementary Education in India', ASARC Working Paper 2011/04.

In 2004-05 number of girls per thousand boys was 954 for illiterate mothers, 910 for mothers with middle school education, 882 for mothers with higher secondary education and 891 for mothers with graduate degrees. This gives a sort of U-shaped curve, the GB being worst among mothers with high school education. In the 1993-94 data set the GB follows a monotonic change from 936 among illiterate mothers to 814 among graduates. The inference from this analysis is rather pessimistic suggesting that education of mothers alone is not going to help to eliminate GB in child population, unless improved beyond high school education. GB in the age group 0-14 years is depicted in the lower panel of Table 2.

\section{District Level Regularity and Change in Gender Bias (1991 and 2001)}

Table 3 provides results of robust estimation of the GB at the level of districts in Census data for 1991 and 2001. Columns (2) and (3) in this table are differentiated by the fact that column (3) includes the percentage of SC and ST in the population. The percentage of population living in urban areas did not affect GB in 1991 but worsened it in 2001. Hence, GB is worse in urban areas. The percentage of children in school reduced GB in 2001 but not in 1991. However, the percentage of girls in school substantially lowered GB in both 1991 and 2001. EAG states had higher GB than the rest of the country. Districts with higher levels of infrastructure development (data available only for 1991) had lower GB. Surprisingly, the higher the percentage of women in the child bearing age group (15-49 years) with education levels higher Secondary or higher the higher the GB. At this level, then, female education is associated with worsening of GB (data available only for 2001). In 2001 the higher the percentage of SC (ST) in the population the higher (lower) was the GB. ${ }^{8}$

\footnotetext{
${ }^{8}$ Appendix Table A2 and A3 respectively, detail the distribution of districts by GB in 1991 and 2001 for 0-6 year olds. Districts are grouped according to whether their GB is below or above average and by whether the percentage of girls (5-14 years) in school is higher or lower than average. Data from the two censuses are compared in Table A4 where we compare districts according to the percentage of girls in school and by whether GB was higher or lower in 2001 as compared to 1991.
} 
Table 3: OLS model with district data, robust SE (The dependent variable is number of girls per 1,000 boys aged 0 to 6)

\begin{tabular}{|c|c|c|c|}
\hline Variables & $\begin{array}{c}(1) \\
1991\end{array}$ & $\begin{array}{c}(2) \\
2001\end{array}$ & $\begin{array}{c}(3) \\
2001\end{array}$ \\
\hline$\%$ of urban population & $\begin{array}{l}-0.334 \\
(0.221)\end{array}$ & $\begin{array}{l}-0.341^{\text {t*k }} \\
(0.103)\end{array}$ & $\begin{array}{l}-0.329^{*+N} \\
(0.0903)\end{array}$ \\
\hline$\%$ of children ( $0-6$ years) & $\begin{array}{l}-1.432 \\
(1.012)\end{array}$ & $\begin{array}{l}2.854^{\text {*tox }} \\
(0.709)\end{array}$ & $\begin{array}{l}-0.164 \\
(0.681)\end{array}$ \\
\hline$\%$ girls in school & $\begin{array}{l}2.360^{* * *} \\
(0.378)\end{array}$ & $\begin{array}{l}8.582^{*+*} \\
(0.844)\end{array}$ & $\begin{array}{l}6.827^{4+4} \\
(0.743)\end{array}$ \\
\hline EAG states & $\begin{array}{l}10.39^{* *} \\
(4.951)\end{array}$ & $\begin{array}{l}11.49^{\text {tht }} \\
(4.216)\end{array}$ & $\begin{array}{l}24.04^{4+4} \\
(4.175)\end{array}$ \\
\hline Development Index & $\begin{array}{l}-0.228^{*} \\
(0.129)\end{array}$ & & \\
\hline $\begin{array}{l}\% \text { of female(15-49) with higher secondary education } \\
\text { and above }\end{array}$ & & $\begin{array}{l}-1.791^{\text {tht }} \\
(0.366)\end{array}$ & $\begin{array}{l}-1.883^{+*+1} \\
(0.320)\end{array}$ \\
\hline$\%$ of SC population & & & $\begin{array}{l}-1.796^{\text {tw }} \\
(0.296)\end{array}$ \\
\hline$\%$ of ST population & & & $\begin{array}{l}0.209^{\text {t+kx }} \\
(0.0738\end{array}$ \\
\hline Constant & $\begin{array}{l}896.7^{* \star *} \\
(31.80)\end{array}$ & $\begin{array}{l}556.3^{\text {t*k }} \\
(42.94)\end{array}$ & $\begin{array}{l}704.4^{4+k+} \\
(38.66)\end{array}$ \\
\hline Observations & 333 & 594 & 594 \\
\hline F-statistics & $17.11^{* * *}$ & $37.40^{* * k}$ & $50.78^{k * k}$ \\
\hline Adjusted R2 & 0.233 & 0.229 & 0.368 \\
\hline
\end{tabular}

Standard errors in parentheses; ${ }^{*} p<=0.10,{ }^{* *} p<=0.05,{ }^{* * * *} p<=0.01$

Notes: (i) $\%$ of urban population $=$ Total urban population $\star 100 /$ Total population

(ii) $\%$ of children ( 0 -6years) $=$ Total children $(0-6$ years)/Total population

(iii) \% of girls in school= Number of girls (5-14 years) in school/Total children in school

(iv) Development Index: Index of Infrastructure Development (Index 85)

(v) \% of female (15-49) with higher secondary education and above = Total female (15-49) with higher secondary education and above/Total female and male with higher secondary education and above.

Source: Census of Indiia 1991 and 2001.

To explore the impact for GB on 0-6year olds we ran robust regressions on GB for this group and report the results in Table 4. The higher the percentage of urban population the greater was the GB both 1991 and 2001. In 2001 the higher the percentage of children in 0-6 age group, the higher was the GB. This indicates that larger household size is associated with lower GB, the higher the Total Fertility Rate the lower the GB. This effect was insignificant in 1991. In 2001 EAG states had higher GB (this effect was insignificant in 1991).

To explore the impact of income/expenditure on GB we ran regressions of GB at the district level using census data for 1991 \& 2001. We discover that urbanization and the percentage of children (0-6 years) are associated with deterioration in the GB. The percentage of girls not in school was, by and large, insignificant. EAG states had poorer GB than ROS. The SC dummy was negative and significant indicating worse GB whereas the opposite was true for ST. 
Table 4: OLS model with district data, robust SE (the dependent variable is the number of girls per 1,000 boys 0-6 years)

\begin{tabular}{|c|c|c|c|}
\hline \multirow[t]{2}{*}{ Variables } & (1) & (2) & (3) \\
\hline & 1991 & 2001 & 2001 \\
\hline$\%$ of urban population & $\begin{array}{l}-0.713^{\text {thx }} \\
(0.177)\end{array}$ & $\begin{array}{l}-0.592^{+k x} \\
(0.110)\end{array}$ & $\begin{array}{l}-0.437^{\text {thx }} \\
(0.104)\end{array}$ \\
\hline$\%$ of children (0-6 years) & $\begin{array}{l}-5.665^{\text {twk }} \\
(1.312)\end{array}$ & $\begin{array}{l}-3.312^{+k+k} \\
(0.927)\end{array}$ & $\begin{array}{l}-4.805^{\text {thx }} \\
(0.884)\end{array}$ \\
\hline$\%$ girls not in school & $\begin{array}{c}0.928^{\text {t*k }} \\
(0.348)\end{array}$ & $\begin{array}{c}0.344 \\
(0.228)\end{array}$ & $\begin{array}{c}0.107 \\
(0.219)\end{array}$ \\
\hline$\%$ girls not in school ${ }^{*} \mathrm{NPH}$ & $\begin{array}{c}0.0228 \\
(0.193)\end{array}$ & $\begin{array}{l}-3.406^{\text {thx }} \\
(0.587)\end{array}$ & $\begin{array}{l}-3.010^{\text {thx }} \\
(0.543)\end{array}$ \\
\hline Female literacy rate & $\begin{array}{c}0.761 \\
(0.509)\end{array}$ & $\begin{array}{c}-0.521^{*} \\
(0.308)\end{array}$ & $\begin{array}{l}-0.905^{\text {thx }} \\
(0.275)\end{array}$ \\
\hline Female literacy rate * NPH & $\begin{array}{l}-0.403^{\text {** }} \\
(0.168)\end{array}$ & $\begin{array}{c}0.189 \\
(0.227)\end{array}$ & $\begin{array}{c}0.338^{\star} \\
(0.201)\end{array}$ \\
\hline EAG states & $\begin{array}{l}-0.823 \\
(4.666)\end{array}$ & $\begin{array}{c}-16.61^{\text {tit }} \\
(3.549)\end{array}$ & $\begin{array}{l}-0.220 \\
(3.617)\end{array}$ \\
\hline$\%$ of SC population & & & $\begin{array}{l}-1.078^{\text {thx }} \\
(0.294)\end{array}$ \\
\hline$\%$ of ST population & & & $\begin{array}{c}0.383^{\text {thx }} \\
(0.0750)\end{array}$ \\
\hline Constant & $\begin{array}{l}986.0^{\text {th+x }} \\
(47.23)\end{array}$ & $\begin{array}{r}1025.1^{\text {t*t* }} \\
(24.93)\end{array}$ & $\begin{array}{r}1070.7^{+3 * x} \\
(24.07)\end{array}$ \\
\hline Observations & 353 & 593 & 593 \\
\hline F-statistics & $6.613^{* \text { *t* }}$ & $22.23^{* * *}$ & $32.56^{\text {t*x }}$ \\
\hline Adjusted $\mathrm{R}^{2}$ & 0.136 & 0.275 & 0.376 \\
\hline
\end{tabular}

Notes: 1 . Standard errors in parentheses; ${ }^{*} p<=0.10,{ }^{* *} p<=0.05,{ }^{* * *} p<=0.01$

2. $\%$ of urban population $=$ District population in urban areas $100 /$ total district population

3. $\%$ of children $(0-6$ years) $=$ District population of children $(0-6$ years $) * 100 /$ total district population

4. $\%$ girls not in school $=\#$ of girls not in school in a district ${ }^{*} 100 /$ total girls in that district

5. NPH: $=1$ if a state had the percentage of child population (0-6 years) in Non-poor High income group larger than 20 percent.

6. Female literacy rate $=\%$ female literates/total female

7. EAG states: $=1$ if EAG

8. $\%$ of SC population = District population in SC * $100 /$ total district population

9. $\%$ of ST population $=$ District population in ST $* 100 /$ total district population,

Source: Census of India 1991 and 2001 B and C Tables.

\section{Gender Bias, Female Education and Expenditure Class Results (Household Data based)}

Whereas the Census data is quite detailed it does not have household level information on consumption, education and other household characteristics that are central to GB. To explore the determinants of GB at the household level we explore household level NSS data for 1993-94 and 2004-05, i.e., 50 ${ }^{\text {th }}$ and $61^{\text {st }}$ rounds of NSS. Results from a base estimation of GB for the two samples are presented in Table 5. 
Table 5: OLS model with interaction, robust SE (the dependent variable is number of girls per 1,000 boys - 0-6 years)

\begin{tabular}{|c|c|c|c|c|c|c|}
\hline Variables & $\begin{array}{c}\text { 1993-94 } \\
\text { All } \\
(1)\end{array}$ & $\begin{array}{c}1993-94 \\
\text { EAG } \\
(2)\end{array}$ & $\begin{array}{c}1993-94 \\
\text { ROS } \\
(3)\end{array}$ & $\begin{array}{c}2004-05 \\
\text { All } \\
(4)\end{array}$ & $\begin{array}{c}2004-05 \\
\text { EAG } \\
(5)\end{array}$ & $\begin{array}{c}2004-05 \\
\text { ROS } \\
(6)\end{array}$ \\
\hline Average education level of females ${ }^{+}$ & $\begin{array}{l}-32.98^{\text {t*k }} \\
(3.813)\end{array}$ & $\begin{array}{c}-37.74^{\text {*k+k}} \\
(7.370)\end{array}$ & $\begin{array}{c}-28.93^{\text {t*k }} \\
(4.620)\end{array}$ & $\begin{array}{c}-38.16^{\text {t*k }} \\
(3.594)\end{array}$ & $\begin{array}{c}-44.95^{\text {t*t+}} \\
(6.726)\end{array}$ & $\begin{array}{c}-28.93^{* * k} \\
(4.465)\end{array}$ \\
\hline Per capita expenditure & $\begin{array}{l}-0.541 \\
(3.007)\end{array}$ & $\begin{array}{c}-0.0882 \\
(4.978)\end{array}$ & $\begin{array}{c}0.519 \\
(3.711)\end{array}$ & $\begin{array}{l}-10.34^{*+* x} \\
(2.431)\end{array}$ & $\begin{array}{c}-12.47^{\text {t+k+ }} \\
(4.844)\end{array}$ & $\begin{array}{c}-7.036^{\text {t*x }} \\
(2.846)\end{array}$ \\
\hline Education of females $x$ MPCE & $\begin{array}{c}0.806 \\
(0.685)\end{array}$ & $\begin{array}{l}1.497 \\
(1.349)\end{array}$ & $\begin{array}{c}0.431 \\
(0.811)\end{array}$ & $\begin{array}{l}1.895^{+2 *+x} \\
(0.420)\end{array}$ & $\begin{array}{l}2.801^{\star * *} \\
(0.957)\end{array}$ & $\begin{array}{l}1.076 \text { t* } \\
(0.470)\end{array}$ \\
\hline Scheduled Caste & $\begin{array}{l}-20.42 \\
(12.92)\end{array}$ & $\begin{array}{l}-33.63^{*} \\
(19.46)\end{array}$ & $\begin{array}{l}-8.998 \\
(17.22)\end{array}$ & $\begin{array}{l}-9.359 \\
(13.00)\end{array}$ & $\begin{array}{l}-12.53 \\
(19.78)\end{array}$ & $\begin{array}{c}-3.731 \\
(16.59)\end{array}$ \\
\hline Scheduled Tribe & $\begin{array}{l}-17.80 \\
(14.16)\end{array}$ & $\begin{array}{l}-26.30 \\
(25.25)\end{array}$ & $\begin{array}{l}-8.227 \\
(17.02)\end{array}$ & $\begin{array}{c}-40.60^{+4+4} \\
(13.56)\end{array}$ & $\begin{array}{l}-69.03^{\text {tot+4}} \\
(24.68)\end{array}$ & $\begin{array}{l}-17.30 \\
(16.09)\end{array}$ \\
\hline Muslim & $\begin{array}{c}7.099 \\
(14.76)\end{array}$ & $\begin{array}{l}-14.39 \\
(24.18)\end{array}$ & $\begin{array}{l}22.66 \\
(18.43)\end{array}$ & $\begin{array}{l}14.36 \\
(14.66)\end{array}$ & $\begin{array}{c}35.64 \\
(25.29)\end{array}$ & $\begin{array}{c}7.117 \\
(17.40)\end{array}$ \\
\hline Dummy = 1 if rural & $\begin{array}{l}-3.310 \\
(10.47)\end{array}$ & $\begin{array}{l}-22.22 \\
(18.49)\end{array}$ & $\begin{array}{c}6.967 \\
(12.38)\end{array}$ & $\begin{array}{l}11.30 \\
(10.34)\end{array}$ & $\begin{array}{l}36.07^{\text {}} \\
(17.50)\end{array}$ & $\begin{array}{l}-7.247 \\
(12.48)\end{array}$ \\
\hline Constant & $\begin{array}{c}1,175.8^{+1+x} \\
(15.06)\end{array}$ & $\begin{array}{c}1,208.0^{\text {tht }} \\
(25.31)\end{array}$ & $\begin{array}{c}1,147.5^{\text {tht }} \\
(18.44)\end{array}$ & $\begin{array}{c}1,228.1^{\text {th }} \\
(17.72)\end{array}$ & $\begin{array}{c}1,234.0^{\text {t*t* }} \\
(29.51)\end{array}$ & $\begin{array}{c}1,198.1^{\text {t*t }} \\
(22.93)\end{array}$ \\
\hline Observations & 16,263 & 7,417 & 8,846 & 14,940 & 7,125 & 7,815 \\
\hline F-statistics & 29.85 & 8.450 & 19.87 & 33.72 & 14.18 & 15.38 \\
\hline Adjusted R² & 0.00661 & 0.00368 & 0.00777 & 0.0112 & 0.00935 & 0.00865 \\
\hline
\end{tabular}

Notes: (1) Standard errors in parentheses

(2) ${ }^{*} p<=0.10,{ }^{* *} p<=0.05,{ }^{* * *} p<=0.01$

(3) + Coefficients are statistically different at the one percent significant level between EAG and ROS groups as well as between 1993-94 and 2004-05

(4) The sample includes households having at least one boy and one girl at the age of 0-6 years old

(5) Average education level of females: Total years of schooling of females in a household/\# of females

(6) Per capita expenditure has a unit of hundred Rupees

(7) Education of female $\times$ MPCE $=$ Average education level of females $\times$ Per capita expenditure

(8) Dummies = 1 if SC, ST, Muslim or rural areas

Source: Calculated from NSS $50^{\text {th }}$ and $61^{\text {st }}$

A basic insight from this analysis is that higher education and higher MPCE, by themselves, actually lead to worsening of GB. However, an increase in the value of the interaction between female education and MPCE is associated with a drop in GB, and suggest that higher education of females and higher per capita expenditure together could lead to lower GB. These results are borne out in a series of regressions for the two samples and for EAG and ROS (e.g. Table 6) and are, therefore, quite robust.

To further analyze the impact of the variable education of females*MPCE we present some suggestive results in Table 7 where the number of girls per 1000 boys in the age group 0-6 is explained by average education of females in the age group 15-49, the MPCE, dummies for SC and households and five interactive variables. Interactive variable $i$ is defined as average female education in the household*MPCE*dummy for the ith income quintile. For both 1993-94 and 2004-05 this equation is estimated for all households in the two samples, for households in the EAG states and those in ROS. 
Table 6- OLS model, robust SE

(The dependent variable is number of girls per 1,000 boys aged 0 to 6 )

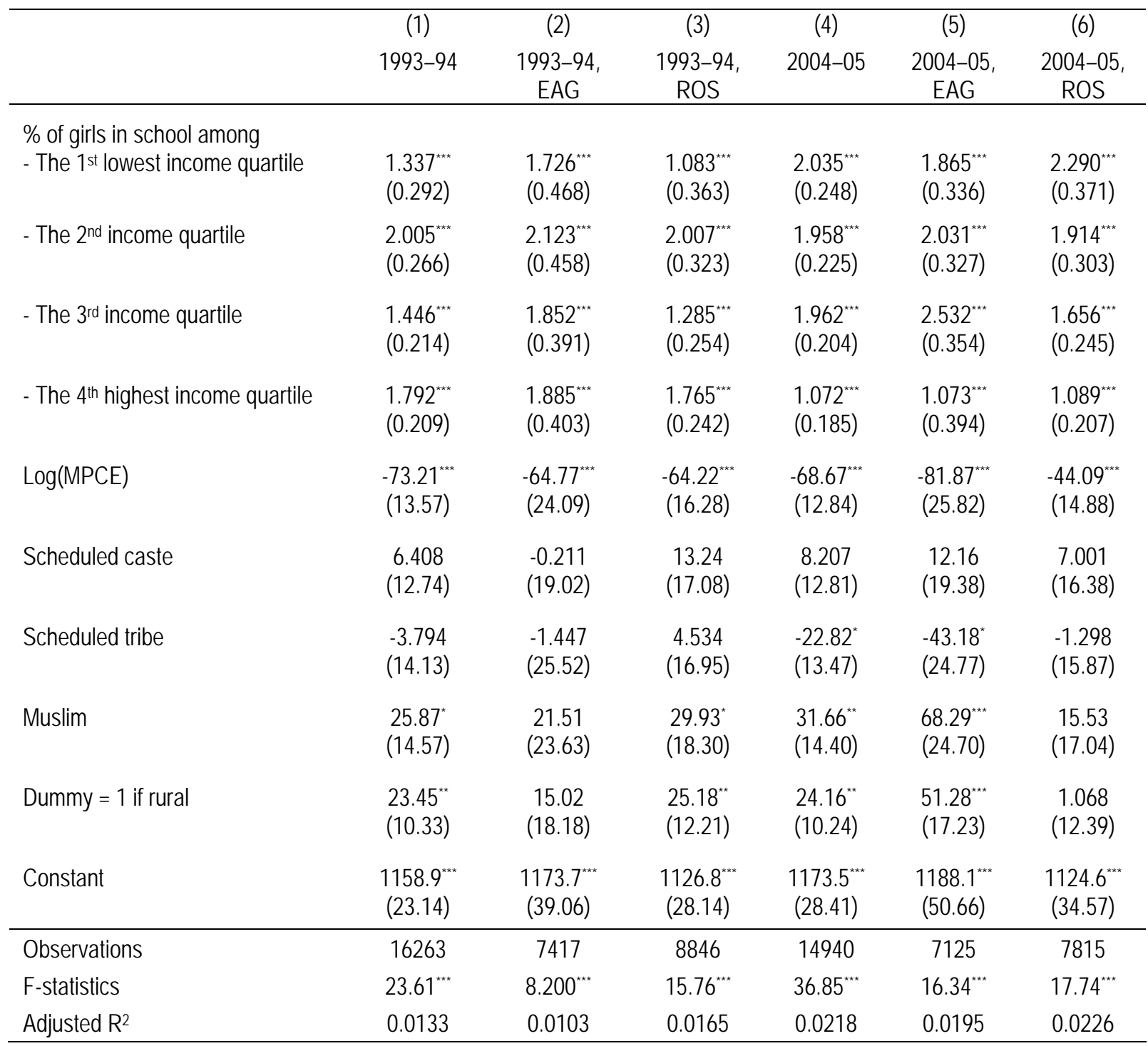

Notes: Standard errors in parentheses ${ }^{*} p<=0.10,{ }^{* *} p<=0.05,{ }^{* * *} p<=0.01$

Source: Calculated from NSS $50^{\text {th }}$ and NSS $61^{\text {st }}$

In all the regressions higher average education of females is associated with worsening of the GB. MPCE was insignificant in the 1993-94 regressions but significant in all the 2004-05 regressions. Interaction variable lowered GB in the EAG states in 1993-94. Interaction variable 2 lowered GB in the full 1993-94 sample and the EAG sample as well. Interaction variable 3 raised GB in 1993-94 in ROS. Interaction variable 4 was insignificant throughout. Interaction variable 5 lowered GB in the full 1993-94 sample and the EAG sample. The same conclusions are warranted for the more recent 2004-05 sample. Hence, reversal of GB is predicated upon households having high MPCE and high levels of education of women in the 15-49 age group. Thus, there should be a U-shaped relation between number of girls per 1000 boys and the variable average female (15-49) education and MPCE. This is borne out by non-parametric and semi-parametric estimation of the relation between these two variables reported in Figure 9. 
Table 7: OLS model, robust SE

\begin{tabular}{|c|c|c|c|c|c|c|}
\hline & (1) & $\begin{array}{l}\text { (2) } \\
1993-94\end{array}$ & (3) & (4) & $\begin{array}{c}\text { (5) } \\
2004-05 . F A G\end{array}$ & $\begin{array}{c}(6) \\
2004-05 \text { ROS }\end{array}$ \\
\hline aveduf_1 & $\begin{array}{l}-0.0800 \\
(0.0860)\end{array}$ & $\begin{array}{l}-0.0230 \\
(0.129)\end{array}$ & $\begin{array}{l}-0.115 \\
(0.117)\end{array}$ & $\begin{array}{l}-0.0615^{\text {t* }} \\
(0.0256)\end{array}$ & $\begin{array}{l}-0.0716^{*} \\
(0.0378)\end{array}$ & $\begin{array}{c}-0.0453 \\
(0.0345)\end{array}$ \\
\hline aveduf_2 & $\begin{array}{l}-0.0688^{\star} \\
(0.0391)\end{array}$ & $\begin{array}{l}-0.0838 \\
(0.0717)\end{array}$ & $\begin{array}{c}-0.0526 \\
(0.0462)\end{array}$ & $\begin{array}{c}-0.0702^{*+1+x} \\
(0.0143)\end{array}$ & $\begin{array}{c}-0.0886^{\text {thx }} \\
(0.0229)\end{array}$ & $\begin{array}{c}-0.0456^{\text {the }} \\
(0.0180)\end{array}$ \\
\hline aveduf_3 & $\begin{array}{l}-0.145^{*+*} \\
(0.0197)\end{array}$ & $\begin{array}{l}-0.141^{*+*} \\
(0.0372)\end{array}$ & $\begin{array}{l}-0.140^{+4+4} \\
(0.0229)\end{array}$ & $\begin{array}{l}-0.0594^{*+1+x} \\
(0.00886)\end{array}$ & $\begin{array}{c}-0.0582^{\text {thx }} \\
(0.0160)\end{array}$ & $\begin{array}{c}-0.0507^{\text {thx }} \\
(0.0103)\end{array}$ \\
\hline aveduf_4 & $\begin{array}{l}-0.0952^{\text {thx }} \\
(0.0115)\end{array}$ & $\begin{array}{l}-0.106^{\text {thx }} \\
(0.0227)\end{array}$ & $\begin{array}{c}-0.0842^{\text {thit }} \\
(0.0133)\end{array}$ & $\begin{array}{l}-0.0465^{\text {tat }} \\
(0.00561)\end{array}$ & $\begin{array}{l}-0.0568^{\text {thx }} \\
(0.00979)\end{array}$ & $\begin{array}{l}-0.0329^{\text {thk }} \\
(0.00684)\end{array}$ \\
\hline aveduf_5 & $\begin{array}{l}-0.0282^{k+k} \\
(0.00317)\end{array}$ & $\begin{array}{l}-0.0330^{\text {*** }} \\
(0.00767)\end{array}$ & $\begin{array}{l}-0.0239^{*+*} \\
(0.00327)\end{array}$ & $\begin{array}{l}-0.0169^{*+1} \\
(0.00158)\end{array}$ & $\begin{array}{l}-0.0178^{\text {tk+ }} \\
(0.00420)\end{array}$ & $\begin{array}{l}-0.0141^{\text {tat }} \\
(0.00162)\end{array}$ \\
\hline Scheduled caste & $\begin{array}{l}-15.28 \\
(12.80)\end{array}$ & $\begin{array}{l}-27.69 \\
(19.26)\end{array}$ & $\begin{array}{l}-4.970 \\
(17.10)\end{array}$ & $\begin{array}{c}0.503 \\
(12.93)\end{array}$ & $\begin{array}{l}-2.658 \\
(19.64)\end{array}$ & $\begin{array}{c}4.551 \\
(16.54)\end{array}$ \\
\hline Scheduled tribe & $\begin{array}{l}-17.03 \\
(14.17)\end{array}$ & $\begin{array}{l}-21.83 \\
(25.06)\end{array}$ & $\begin{array}{l}-9.225 \\
(17.07)\end{array}$ & $\begin{array}{l}-39.78^{\text {tok }} \\
(13.56)\end{array}$ & $\begin{array}{l}-57.12^{\text {** }} \\
(24.42)\end{array}$ & $\begin{array}{l}-18.05 \\
(16.08)\end{array}$ \\
\hline Muslim & $\begin{array}{c}12.58 \\
(14.65)\end{array}$ & $\begin{array}{l}-8.066 \\
(23.89)\end{array}$ & $\begin{array}{c}26.74 \\
(18.40)\end{array}$ & $\begin{array}{c}19.41 \\
(14.65)\end{array}$ & $\begin{array}{l}41.37^{\star} \\
(25.22)\end{array}$ & $\begin{array}{c}11.96 \\
(17.39)\end{array}$ \\
\hline Dummy = 1 if rural & $\begin{array}{c}4.543 \\
(10.25)\end{array}$ & $\begin{array}{l}-16.55 \\
(18.18)\end{array}$ & $\begin{array}{c}15.12 \\
(12.14)\end{array}$ & $\begin{array}{l}19.82^{* *} \\
(10.32)\end{array}$ & $\begin{array}{l}42.14^{* *} \\
(17.53)\end{array}$ & $\begin{array}{l}-0.771 \\
(12.43)\end{array}$ \\
\hline Constant & $\begin{array}{l}1158.3^{+4 k x} \\
(10.57)\end{array}$ & $\begin{array}{c}1193.8^{*+* k} \\
(19.20)\end{array}$ & $\begin{array}{c}1132.4^{4+k} \\
(12.17)\end{array}$ & $\begin{array}{c}1160.6^{\text {tht }} \\
(11.19)\end{array}$ & $\begin{array}{c}1165.8^{\text {tht }} \\
(18.61)\end{array}$ & $\begin{array}{c}1142.2^{4+k} \\
(13.71)\end{array}$ \\
\hline Observations & 16263 & 7417 & 8846 & 14940 & 7125 & 7815 \\
\hline F-statistics & $18.94^{* * *}$ & $4.919^{\text {t*kt}}$ & $12.65^{\text {***}}$ & $22.57^{* * * k}$ & $9.084^{* \star * x}$ & $10.93^{\text {t*k}}$ \\
\hline Adjusted $\mathrm{R}^{2}$ & 0.00539 & 0.00244 & 0.00657 & 0.00861 & 0.00721 & 0.00639 \\
\hline
\end{tabular}

Notes: (i) Standard errors in parentheses

(ii) ${ }^{*} p<=0.10,{ }^{* *} p<=0.05,{ }^{* * *} p<=0.01$

(iii) Interaction $i=$ Average female education * MPCE * Dummy of the ith income quantile

Source: Calculated from NSS 50th and NSS 61st

\section{Conclusions and Policy Implications}

This paper has studied the evolution of GB in the age group 0-6 in India and its association with education and higher prosperity. GB among children 0-6 years is pervasive in India and has grown over time with higher prosperity and resultant demographic transition and enhanced education. The number of children in the age group 0-14 peaked in 2001 and has, since, been falling. Even as the under 5 mortality rate has fallen from 240.1 per thousand in the 1961 census to 65.6 in 2011, the total fertility rate has experienced an equally sharp decline from 6.1 in 1961 to 2.6 in 2011. That large household size (associated with high fertility rates and low MPCE) is linked with low GB comes as no surprise. However, with higher prosperity and lower TFR GB rises sharply. The percentage difference in GB in successive time periods fell from 0.3 in 1951 to 0.1 in 1961 but accelerated to 1.9 in 2011. The GB is higher in the age group $0-4$ than in the age group $0-6$. GB has actually improved for the age group 10-14 but this fact is irrelevant for the evolution of GB in children since children in that age group will soon be adults. Hence, the outlook for GB in the age group 0 6 years appears bleak at least until 2026. 
Figure 9:

Non-parametric and semi-parametric techniques

(a) 1993-94

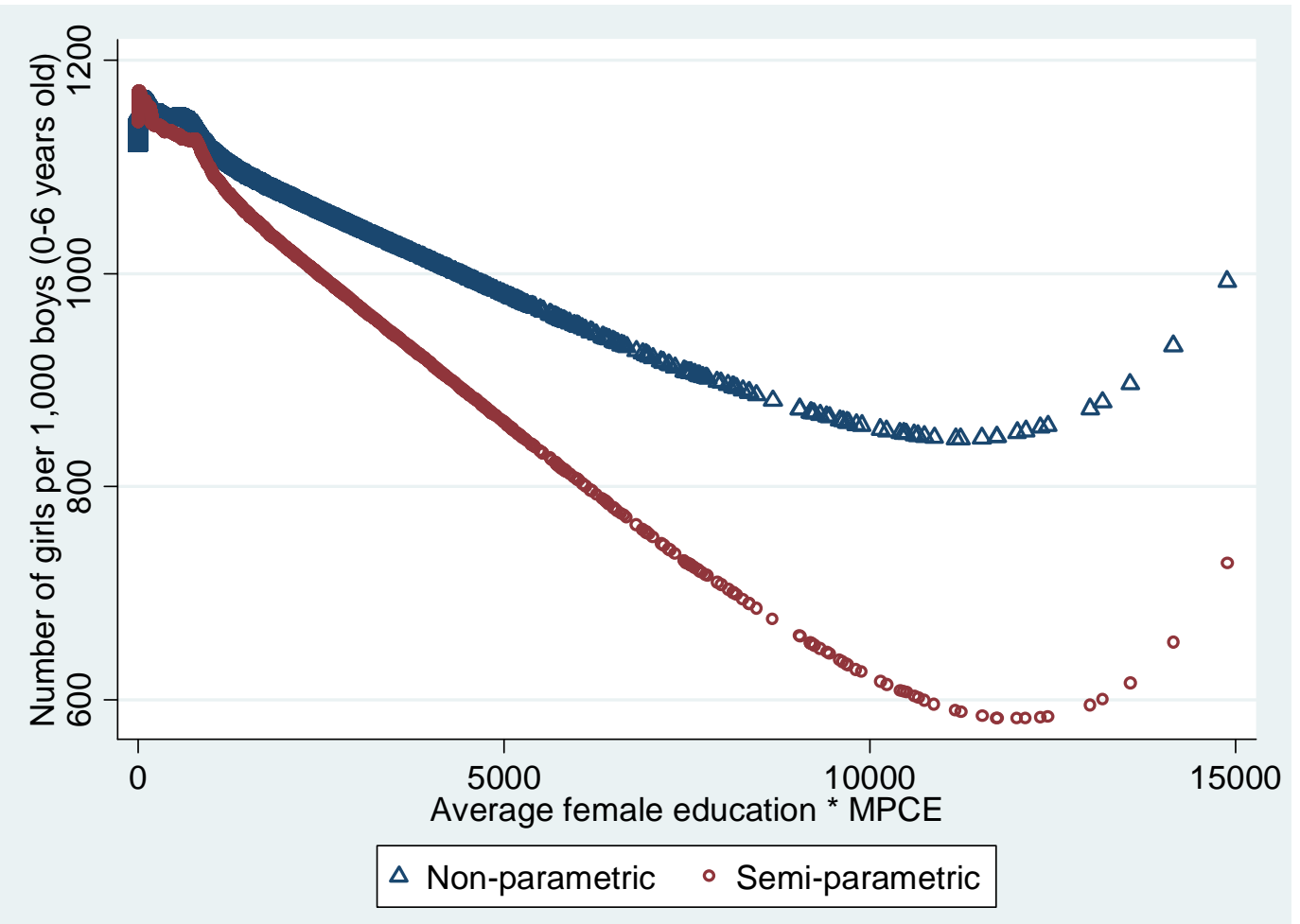

(b) 2004-05

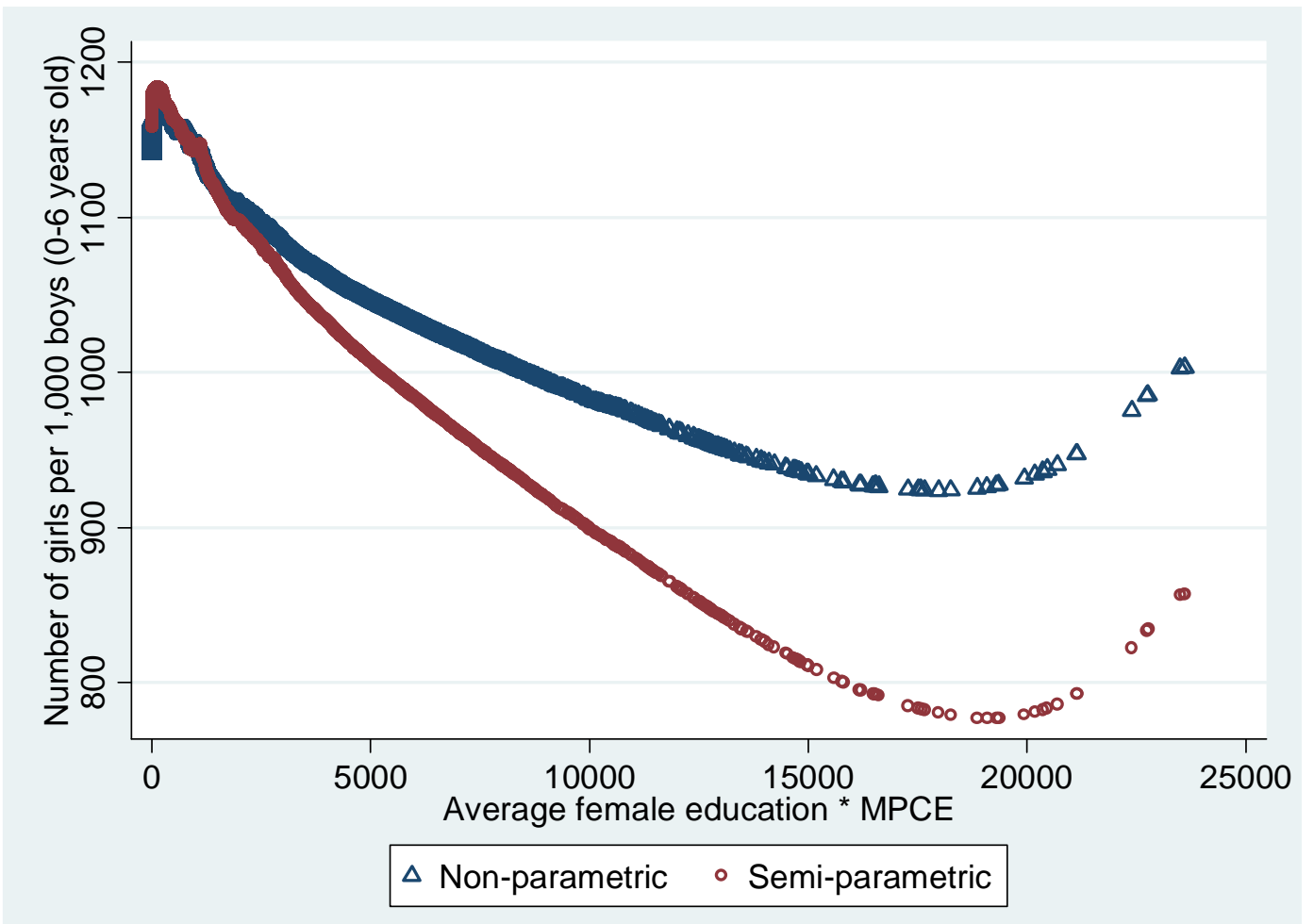


The paper also demonstrates that there are wide variations in GB across various states, even districts, of India. In 2011 child population is still high in the EAG states whereas the growth of child population has come down substantially in some states, particularly some southern states and Himachal Pradesh.

At the district level we discover that the education of girls is an important determinant of GB. At the household level both improved education of females in the age group 15-49 and higher prosperity lead to worsening of GB. However, at high values of the interaction of these two variables there could be a turnaround in the trend of worsening GB. At present trends, however, this is unlikely to happen at least until 2026. More positive outcomes require social engineering through multidimensional, orchestrated policies. Positive signs are discernable in some districts, states and households. In 55 districts GB declined and proportion of girls attending schools increased. Kerala \& Tamil Nadu did not have any worsening of GB while it improved in Himachal Pradesh. Finally, prosperity improved GB among SC, ST and Muslims and households having women in child bearing age with graduate degrees.

\section{References}

Chaudhri, D.P. (1996), A Dynamic Profile of Child Labour in India New Delhi: International Labour Office.

Chaudhri, D.P. and R. Jha (2011a) 'Child Poverty and Compulsory Education in India: Policy Insights from Household Data Analysis’ ASARC Working Paper 2011/04.

Chaudhri, D.P. and R. Jha (2011b) 'Money Does Buy Child’s Gender' Economic Times, New Delhi, June.

Dasgupta, M. and S. Li (1999), 'Gender Bias in China, South Korea and India 1920-1990: The Effects of War, Famine and Fertility Decline’, Development and Change, 30(3): 619-52, Special Issue on Gendered Poverty and Wellbeing (ed. Shahra Razavi).

Government of India, (2009), The Rights of Children to Free and Compulsory Education Act 2009, The Gazette of India, No 39, Ministry of Law and Justice, New Delhi.

Johansson, S. and O. Nygren. (1991). 'The Missing Girls of China: A new demographic account'. Population and Development Review, 17: 35-51

MHRD (2009), Website: http://www.education.nic.in/ for details on the 2009 Act.

Li S. (2007), 'Imbalanced Sex Ratio at Birth and Comprehensive Intervention in China', 4th Asia Pacific Conference on Reproductive and Sexual Health and Rights, October 2007; Hyderabad, India.

National Sample Survey (2011) Details of National Sample Survey data available at http://mospi.nic.in/nsso_4aug2008/web/nsso.htm

NUEPA (2011) on Education Data http://www.education.nic.in/ and also http://www.dise.in/ for recent details. Accessed August 2011.

Premi, M., (2001), 'The Missing Girl Child', Economic and Political Weekly, 36(21), pp.1875-80.

Rustagi, P. and R. Mitra (2008), 'South Asia Regional Child Poverty Network', PPP at 7-9 May 2008 meeting sponsored by UNICEF, New Delhi.

Registrar General of India (1991), Census of India 1991, New Delhi: Registrar General's Office.

Registrar General of India (2001), Census of India 2011, New Delhi: Registrar General’s Office.

Registrar General of India (2006), Expert Committee Report on Population Projections till 2026, New Delhi: Registrar General's Office.

Registrar General of India (2011), Census of India 2011, New Delhi: Registrar General’s Office.

UNDP (2010), Human Development Report 2010, UNDP, New York.

UNICEF (1989), Rights of The Child, UNICEF, New York.

Weiner, M. (1991), The Child and The State in India, Princeton: Princeton University Press.

World Bank (2011) Data Base/India for Child Mortality Rates, IBRD, Washington D.C.

Zeng, Y., Ping, T., Baochang, G., Yi, X., Bohua, L. and Y. Li (1993), 'Causes and Implications of the Recent Increase in the Reported Sex Ratio at Birth in China', Population and Development Review, 19(2): 283-302. 
Appendix Table A1: Child population (0-6 years) (unit: thousand children)

\begin{tabular}{|c|c|c|c|c|c|c|c|c|c|c|c|c|c|c|c|c|}
\hline & \multicolumn{2}{|c|}{1991} & \multicolumn{2}{|c|}{2001} & \multicolumn{2}{|c|}{2011} & \multicolumn{2}{|c|}{ 1993-94 } & \multicolumn{2}{|c|}{ 2004-05 } & \multicolumn{2}{|c|}{$\begin{array}{l}\text { Change in } \\
1991-2001\end{array}$} & \multicolumn{2}{|c|}{$\begin{array}{l}\text { Change in } \\
2001-2011\end{array}$} & \multicolumn{2}{|c|}{$\begin{array}{l}\text { Change in } \\
1993-2005\end{array}$} \\
\hline & Total & $\mathbf{G B}^{*}$ & Total & $\mathbf{G B}^{*}$ & Total & $\mathrm{GB}^{*}$ & Total & $\mathbf{G B}^{*}$ & Total & $\mathbf{G B}^{*}$ & Total & $\mathrm{GB}^{*}$ & Total & $\mathbf{G B}^{*}$ & Total & $\mathbf{G B}^{\star}$ \\
\hline & (1) & (2) & (3) & $(4)$ & $(5)$ & $(6)$ & $(7)$ & (8) & $(9)$ & (10) & (11) & (12) & (13) & (14) & (15) & (16) \\
\hline All India & 150,081 & 945 & 163,820 & 927 & 158,789 & 914 & 135,450 & 923 & 149,033 & 930 & 13,739 & -18 & $-5,031$ & -13 & 13,583 & 7 \\
\hline EAG states & 73,262 & 941 & 85,094 & 930 & 84,550 & 913 & 66,614 & 914 & 80,908 & 933 & 11,832 & -11 & -544 & -17 & 14,294 & 19 \\
\hline Bihar & 17,764 & 959 & 21,763 & 948 & 23,820 & 935 & 14,248 & 904 & 19,608 & 872 & 3,999 & -11 & 2,057 & -13 & 5,360 & -32 \\
\hline Uttar Pradesh & 28,200 & 928 & 32,985 & 915 & 31,057 & 899 & 27,450 & 894 & 32,502 & 960 & 4,785 & -13 & $-1,928$ & -16 & 5,052 & 66 \\
\hline Rajasthan & 8,859 & 916 & 10,651 & 909 & 10,505 & 883 & 7,735 & 938 & 9,764 & 907 & 1,792 & -7 & -146 & -26 & 2,029 & -31 \\
\hline Madhya Pradesh & 13,092 & 952 & 14,337 & 943 & 14,132 & 925 & 11,946 & 947 & 13,731 & 973 & 1,245 & -9 & -205 & -18 & 1,785 & 26 \\
\hline Orissa & 5,348 & 967 & 5,359 & 953 & 5,036 & 934 & 5,235 & 939 & 5,303 & 952 & 11 & -14 & -323 & -19 & 68 & 13 \\
\hline Non-EAG states & 5,416 & 971 & 6,963 & 951 & 7,473 & 924 & 4,464 & 878 & 5,537 & 893 & 1,547 & -20 & 510 & -27 & 1,073 & 15 \\
\hline Dadra \& Nagar Haveli & 28 & 1,013 & 40 & 979 & 49 & 924 & 23 & 828 & 34 & 1,235 & 12 & -34 & 9 & -55 & 11 & 407 \\
\hline Haryana & 3,125 & 879 & 3,336 & 819 & 3,298 & 830 & 3,355 & 874 & 3,314 & 973 & 211 & -60 & -38 & 11 & -41 & 99 \\
\hline Assam & 4,422 & 975 & 4,498 & 965 & 4,511 & 957 & 3,146 & 879 & 3,786 & 862 & 76 & -10 & 13 & -8 & 640 & -17 \\
\hline Gujrat & 6,502 & 928 & 7,532 & 883 & 7,494 & 886 & 6,216 & 857 & 6,634 & 906 & 1,030 & -45 & -38 & 3 & 418 & 49 \\
\hline Goa & 137 & 964 & 146 & 938 & 139 & 920 & 80 & 790 & 137 & 1,253 & 9 & -26 & -7 & -18 & 57 & 463 \\
\hline West Bengal & 11,562 & 967 & 11,414 & 960 & 10,113 & 950 & 10,799 & 950 & 10,290 & 981 & -148 & -7 & $-1,301$ & -10 & -509 & 31 \\
\hline Maharastra & 13,505 & 946 & 13,671 & 913 & 12,848 & 883 & 11,446 & 952 & 11,797 & 854 & 166 & -33 & -823 & -30 & 351 & -98 \\
\hline Himachal Pradesh & 829 & 951 & 793 & 896 & 764 & 906 & 771 & 899 & 772 & 957 & -36 & -55 & -29 & 10 & 1 & 58 \\
\hline Andhra Pradesh & 10,964 & 975 & 10,172 & 961 & 8,643 & 943 & 10,072 & 969 & 9,102 & 962 & -792 & -14 & $-1,529$ & -18 & -970 & -7 \\
\hline Punjab & 3,306 & 875 & 3,172 & 798 & 2,942 & 846 & 3,041 & 829 & 2,960 & 808 & -134 & -77 & -230 & 48 & -81 & -21 \\
\hline Karnataka & 7,478 & 960 & 7,182 & 946 & 6,856 & 943 & 6,699 & 1,010 & 5,909 & 927 & -296 & -14 & -326 & -3 & -790 & -83 \\
\hline Jammu \& Kashmir* & - & - & 1,486 & 941 & 2,009 & 859 & 444 & 859 & 808 & 920 & & & 523 & -82 & 364 & 61 \\
\hline Kerala & 3,837 & 958 & 3,793 & 960 & 3,322 & 959 & 2,713 & 897 & 3,513 & 1,024 & -44 & 2 & -471 & -1 & 800 & 127 \\
\hline Tamil Nadu & 7,448 & 948 & 7,235 & 942 & 6,895 & 946 & 7,385 & 992 & 6,239 & 976 & -213 & -6 & -340 & 4 & $-1,146$ & -16 \\
\hline Delhi & 1,607 & 915 & 2,017 & 868 & 1,971 & 866 & 1,212 & 673 & 1,285 & 894 & 410 & -47 & -46 & -2 & 73 & 221 \\
\hline Others & 2,068 & 972 & 2,238 & 958 & 2,386 & 950 & 1,434 & 915 & 1,545 & 920 & 170 & -14 & 148 & -8 & 111 & 5 \\
\hline
\end{tabular}

Notes: $\left({ }^{\star}\right)$ Gender bias: females per 1,000 males; $\left(^{\star \star}\right)$ Excludes Jammu \& Kashmir where 1991 census was not held.

Ranking according to reducing children proportion of the population. Sources: Census of India 1991, 2001, 2011; Calculated from NSS 50't and 61 ${ }^{\text {st }}$. 
Appendix Table A2: The list of districts in 1991 by average GB (girls aged 0-6 per 1,000 boys) and average girl student share

\begin{tabular}{|c|c|c|}
\hline & Below the average girl student share & Above the average girl student share \\
\hline $\begin{array}{l}\text { Above } \\
\text { the } \\
\text { average } \\
\text { GB }\end{array}$ & $\begin{array}{l}\text { Adilabad, Anantpur, Araria, Aurangabad, Azamgarh, Bahraich, Balangir, } \\
\text { Banswara, Barabanki, Bastar, Begusarai, Bhilwara, Bilaspur, Chamba, } \\
\text { Chittaurgarh, Chittoor, Cuddapah, Darbhanga, Deoghar, Dhanbad, } \\
\text { Dhar, Dibang Valley, Dumka, Dungarpur, East Kameng, East Nimar, } \\
\text { Ganjam, Gaya, Giridih, Godda, Gopalganj, Gulbarga, Hazaribag, Jalna, } \\
\text { Jehanabad, Jhabua, Kalahandi, Karimnagar, Katihar, Kheri, Kishanganj, } \\
\text { Koraput, Kurnool, Madhubani, Mahbubnagar, Mandsaur, Mau, Medak, } \\
\text { Nalanda, Nalgonda, Nanded, Nawada, Nizamabad, Palamu, Panch } \\
\text { Mahals, Panna, Parbhani, Paschim Champaran, Paschimi Singhbhum, } \\
\text { Pilbhit, Prakasam, Purnia, Puruliya, Rae Bareli, Raichur, Rajnandgaon, } \\
\text { Ratlam, Rohtas, Sahibganj, Saran, Shahdol, Sidhi, Sitapur, Siwan, } \\
\text { Sonbhadra, Srikakulam, Surguja, Tehri Garhwal, Udaipur, Uttarkashi, } \\
\text { Vizianagaram, Warangal }\end{array}$ & $\begin{array}{l}\text { Ahmadnagar, Aizaw, Almora, Amravati, Balaghat, Baleshwar, Bangalore, Bangalore Rural, Bankura, } \\
\text { Barddhaman, Barpeta, Belgaum, Bellary, Betul, Bhandara, Bharuch, Bidar, Bijapur, Birbhum, } \\
\text { Bishnupur, Bongaigaon, Cachar, Chamoli, Chandel, Chandrapur, Changlang, Chhindwara, } \\
\text { Chikmagalur, Chitradurga, Churachandpur, Coimbatore, Dakshini Kannada, Dariling, Darrang, } \\
\text { Dhemaji, Dhenkanal, Dhubri, Dibrugaarh, Durg, East Districts, East Gao Hills, East Godavari, East } \\
\text { Khasi Hills, East Siang, Ernakulam, Gadchiroli, Garhwal, Goalpara, Golaghat, Gumla, Guntur, } \\
\text { Hailakandi, Hassan, Hyderabad, Idukki, Imphal, Imphal, Jabalpur, Jaintia Hills, Jalpaiguri, Jorhat, } \\
\text { Kamrup, Kannlyakumari, Kannur, Karbi Anglong, Karimganj, Kasaragod, Kendujhar, Khammam, Koch } \\
\text { Bihar, Kodagu, Kohima, Kokrajhar, Kolar, Kollam, Kottayam, Kozikode, Krishna, Kullu, Lahul and } \\
\text { Spiti, Lakhimpur, Lohardaga, Lohit, Lower Subansiri, Lucknow, Lunglel, Malappuram, Maldah, Mandi, } \\
\text { Mandla, Mandya, Marigaon, Mayurbhanj, Medinipur, Mokokchung, Mon, Murshidabad, Mysore, Nadia, } \\
\text { Nagaon, Nagpur, Nalbari, Nashik, Nilgiri, North, North 24 Parganas, North Cathar Hills, North District, } \\
\text { North Tripura, Palakkad, Pathanamchitta, Phek, Pithoragarh, Pudukkottal, Purbi Singhbhum, Raigarh, } \\
\text { Raipur, Rajgarh, Ramanathapuram, Ranchi, Rangareddy, Ratnagiri, Sambalpur, Senapati, Seoni, } \\
\text { Shimla, Shimoga, Sibsagar, Sindhudurg, Sirmaur, Solan, Sonitpur, South 24 Parganas, South } \\
\text { Districts, South Goa, South Tripura, Sundargarh, Tamenglong, Tawang, Thane, Thanjavur, The } \\
\text { Dangs, Thiruvananthapuram, Thoubal, Thrissur, Tinsukia, Tiruchirapalli, Tuensang, Tumkur, Upper } \\
\text { Subansiri, Uttara Kannada, Valsad, Visakhapatnam, Wardha, Wayanad, West Districts, West Garo } \\
\text { Hills, West Godavari, West Kameng, West Khasi Hills, West Nimar, West Siang, West Tripura, } \\
\text { Wokha, Yavatmal, Zunheboto }\end{array}$ \\
\hline $\begin{array}{l}\text { Below } \\
\text { the } \\
\text { average } \\
\text { GB }\end{array}$ & $\begin{array}{l}\text { Agra, Ajmer, Aligarh, Allahabad, Alwar, Ballia, Banas Kantha, Banda, } \\
\text { Bareilly, Barmer, Basti, Bhagalpur, Bharatpur, Bhind, Bhojpur, Bid, } \\
\text { Bijnor, Bikaner, Budaun, Bulandshahr, Bundi, Chhatarpur, Churu, } \\
\text { Damoh, Datia, Deoria, Dewas, Dholpur, Etah, Faizabad, Faridabad, } \\
\text { Farrukhabad, Fatehpur, Firozabad, Ganganagar, Ghaziabad, Ghazipur, } \\
\text { Gonda, Gorakhpur, Guna, Gurgaon, Gwalior, Hamirpur, Hardoi, } \\
\text { Hardwar, Hisar, Jaipur, Jaisalmer, Jalaun, Jalor, Jaunpur, Jhalawar, } \\
\text { Jhansi, Jhunjhunun, Jind, Jodhpur, Kaithal, Khagaria, Kota, Lalitpur, } \\
\text { Madhepura, Maharajganj, Mainpuri, Mathura, Meerut, Mizapur, } \\
\text { Moradabad, Morena, Munger, Muzaffarnagar, Muzaffarpur, Nagaur, } \\
\text { Pali, Patna, Pratapgarh, Purba Champaran, Rajgarh, Ralsen, Rampur, } \\
\text { Rewa, Saharanpur, Saharsa, Samastipur, Satna, Sawai Madhopur, } \\
\text { Sehore, Shahjahanpur, Shajapur, Shivpuri, Siddharthnagar, Sikar, } \\
\text { Sirohi, Sitamarhi, Sultanpur, Tikamgarh, Tirap, Tonk, Ujjain, Unnao, } \\
\text { Vaishali, Varanasi, Vidisha }\end{array}$ & $\begin{array}{l}\text { Ahmadabad, Akola, Alappuzha, Ambala, Amreli, Amritsar, Aurangabad, Bathinda, Bhavnagar, Bhiwani, } \\
\text { Bhopal, Bilaspur, Buldana, Cuttack, Dehradun, Dharmapuri, Dharwad, Dhule, Dindigul Anna, Etawah, } \\
\text { Faridkot, Firozpur, Gandhinagar, Gurdaspur, Hamirpur, Hoshangabad, Hoshiarpur, Indore, Jalandhar, } \\
\text { Jalgaon, Jamnagar, Junagadh, Kangra, Kanpur - Dehat, Kanpur - Nagar, Kapurthala, Karnal, Kheda, } \\
\text { Kothapur, Kurukshetra, Latur, Ludhiana, Madras, Mahendragarh, Mahesana, Nainital, Narsimhapur, } \\
\text { Nellore, Osmanabad, Panipat, Patiala, Pune, Puri, Rajkot, Rewari, Rohtak, Rupnagar, Sabar Kantha, } \\
\text { Sagar, Salem, Sangil, Sangrur, Satara, Sirsa, Solapur, Sonipat, Surat, Surendranagar, Ukhrul, Una, } \\
\text { Vadodara, Yamunanagar }\end{array}$ \\
\hline
\end{tabular}

Source: Calculated from Census of India 1991, Notes: Pearson chi2(1) $=25.2946 \operatorname{Pr}=0.000$ 
Appendix Table A3: The list of districts in 2001 by average GB (girls aged 0-6 per 1,000 boys) and average girl student share

\begin{tabular}{|c|c|c|}
\hline & Below the average girl student share & Above the average girl student share \\
\hline $\begin{array}{l}\text { Above the } \\
\text { average } \\
\text { GB }\end{array}$ & $\begin{array}{l}\text { Araria, Aurangabad, Bahraich, Ballia, Bankura, Banswara, Barabanki, } \\
\text { Bastar, Basti, Begusarai, Bhagalpur, Bhilwara, Bhojpur, Bilaspur, } \\
\text { Changlang, Chittaurgarh, Damoh, Deoghar, Deoria, Dewas, Dhanbad, } \\
\text { Dhar, Dumka, Dungarpur, East Kameng, East Nimar, Faizabad, Gaya, } \\
\text { Ghazipur, Giridih, Godda, Gonda, Gopalganj, Gorakhpur, Guna, } \\
\text { Hazaribag, Jaunpur, Jhabua, Jhalawar, Kalahandi, Katihar, Khagaria, } \\
\text { Kheri, Kishanganj, Koraput, Kurnool, Lalitpur, Lohardaga, Lohit, } \\
\text { Madhubani, Maharajganj, Mahbubnagar, Mandsaur, Mayurbhanj, } \\
\text { Mirzapur, Nalanda, Nawada, Palamu, Panch Mahals, Panna, Paschim } \\
\text { Champaran, Paschimi Singhbhum, Pilbhit, Pratapgarh, Purba } \\
\text { Champaran, Purnia, Puruliya, Rae Bareli, Raichur, Rajgarh, Ratlam, } \\
\text { Rohtas, Sahibganj, Samastipur, Saran, Shajapur, Siddharthnagar, } \\
\text { Sidhi, Sitapur, Siwan, Sonbhadra, Sultanpur, Tirap, Udaipur, Ujjain, } \\
\text { Vaishali, Vidisha, West Nimar }\end{array}$ & $\begin{array}{l}\text { Adilabad, Aizan, Akola, Alappuzha, Almora, Amravati, Anantpur, Azamgarh, Balaghat, Balangir, } \\
\text { Baleshwar, Bangalore, Bangalore Rural, Barddhaman, Barpeta, Bellary, Betul, Bhandara, Bidar, } \\
\text { Birbhum, Bishnupur, Bongaigaon, Cachar, Chamba, Chamoli, Chandel, Chandrapur, Chhindwara, } \\
\text { Chikmagalur, Chitradurga, Chittoor, Churachandpur, Coimbatore, Cuddapah, Cuttack, Dakshini } \\
\text { Kannada, Darjling, Darrang, Dharwad, Dhemaji, Dhubri, Dibang Valley, Dibrugaarh, Dindigul Anna, } \\
\text { Durg, East Districts, East Gao Hills, East Godavari, East Khasi Hills, East Siang, Ernakulam, } \\
\text { Gadchiroli, Ganjam, Garhwal, Goalpara, Golaghat, Gulbarga, Gumla, Guntur, Hassan, Hyderabad, } \\
\text { Idukki, Imphal, Imphal, Jabalpur, Jaintia Hills, Jalpaiguri, Jorhat, Kamrup, Kannlyakumari, Kannur, } \\
\text { Karbi Anglong, Karimganj, Karimnagar, Kasaragod, Kendujhar, Khammam, Koch Bihar, Kodagu, } \\
\text { Kohima, Kokrajhar, Kolar, Kollam, Kottayam, Kozikode, Krishna, Kullu, Lahul and Spiti, Lakhimpur, } \\
\text { Lower Subansiri, Lunglel, Malappuram, Maldah, Mandlla, Mandya, Marigaon, Mau, Medak, Medinipur, } \\
\text { Mokokchung, Mon, Murshidabad, Mysore, Nadia, Nagaon, Nagpur, Nalbari, Nalgonda, Nanded, } \\
\text { Nellore, Nilgiri, Nizamabad, North, North } 24 \text { Parganas, North Cathar Hills, North District, North Tripura, } \\
\text { Palakkad, Pathanamchitta, Prakasam, Pudukkottal, Purbi Singhbhum, Puri, Raigarh, Raipur, Rajgarh, } \\
\text { Rajnandgaon, Ralsen, Ramanathapuram, Ranchi, Rangareddy, Ratnagiri, Sagar, Sambalpur, Satna, } \\
\text { Senapati, Seoni, Shahdol, Shimla, Shimoga, Sibsagar, Sindhudurg, Sirmaur, Sonitpur, South } 24 \\
\text { Parganas, South Districts, South Goa, South Tripura, Srikakulam, Sundargarh, Surguja, Tamenglong, } \\
\text { Tawang, Thane, Thanjavur, The Dangs, Thiruvananthapuram, Thoubal, Thrissur, Tinsukia, } \\
\text { Tiruchirapalli, Tuensang, Tumkur, Ukhrul, Upper Subansiri, Uttara Kannada, Uttarkashi, Valsad, } \\
\text { Visakhapatnam, Vizianagaram, Warangal, Wayanad, West Districts, West Garo Hills, West Godavari, } \\
\text { West Kameng, West Khasi Hills, West Siang, West Tripura, Wokha, Yavatmal, Zunheboto }\end{array}$ \\
\hline $\begin{array}{l}\text { Below the } \\
\text { average } \\
\text { GB }\end{array}$ & $\begin{array}{l}\text { Agra, Ahmadabad, Ajmer, Aligarh, Allahabad, Alwar, Amritsar, Banas } \\
\text { Kantha, Banda, Bareilly, Barmer, Bathinda, Bharatpur, Bhavnagar, } \\
\text { Bhind, Bhiwani, Bijapur, Bijnor, Bikaner, Budaun, Bulandshahr, Bundi, } \\
\text { Chhatarpur, Churu, Darbhanga, Datia, Dholpur, Etah, Faridabad, } \\
\text { Faridkot, Farrukhabad, Fatehpur, Frrozabad, Frozpur, Gandhinagar, } \\
\text { Ganganagar, Ghaziabad, Gurgaon, Gwalior, Hamirpur, Hardoi, } \\
\text { Hardwar, Hisar, Jaipur, Jaisalmer, Jalaun, Jalor, Jehanabad, Jhansi, } \\
\text { Jhunjhunun, Jind, Jodhpur, Kaithal, Kapurthala, Karnal, Kheda, Kota, } \\
\text { Kurukshetra, Madhepura, Mahesana, Mainpuri, Mathura, Meerut, } \\
\text { Moradabad, Morena, Munger, Muzaffarnagar, Muaffarpur, Nagaur, } \\
\text { Pali, Panipat, Patiala, Patna, Rampur, Sabar Kantha, Saharanpur, } \\
\text { Saharsa, Sangrur, Sawai Madhopur, Sehore, Shahjahanpur, Shivpuri, } \\
\text { Sikar, Sirohi, Sirsa, Sitamarhi, Sonipat, Surendranagar, Tikamgarh, } \\
\text { Tonk, Unnao, Vadodara, Yamunanagar }\end{array}$ & $\begin{array}{l}\text { Ahmadnagar, Ambala, Amreli, Aurangabad, Belgaum, Bharuch, Bhopal, Bid, Bilaspur, Buldana, } \\
\text { Dehradun, Dharmapuri, Dhenkanal, Dhule, Etawah, Gurdaspur, Hailakandi, Hamirpur, Hoshangabad, } \\
\text { Hoshiarpur, Indore, Jalandhar, Jalgaon, Jalna, Jamnagar, Junagadh, Kangra, Kanpur - Dehat, Kanpur - } \\
\text { Nagar, Kothapur, Latur, Lucknow, Ludhiana, Madras, Mahendragarh, Mandi, Nainital, Narsimhapur, } \\
\text { Nashik, Osmanabad, Parbhani, Phek, Pithoragarh, Pune, Rajkot, Rewa, Rewari, Rohtak, Rupnagar, } \\
\text { Salem, Sangil, Satara, Solan, Solapur, Surat, Tehri Garhwal, Una, Varanasi, Wardha, }\end{array}$ \\
\hline
\end{tabular}

Source: Calculated from India Census 2001

Notes: Pearson chi2 $(1)=26.9145 \operatorname{Pr}=0.000$ 
Appendix Table A4: The list of districts in 1991-2001 by change in GB (girls aged 0-6 per 1,000 boys) and change in girl student share

\begin{tabular}{|c|c|c|}
\hline & $\begin{array}{l}\text { The average girl student } \\
\text { share lower in } 2001\end{array}$ & The average girl student share higher in 2001 \\
\hline $\begin{array}{l}\text { The } \\
\text { average } \\
\text { GB } \\
\text { higher in } \\
2001\end{array}$ & $\begin{array}{l}\text { Alappuzha, Churachandpur, } \\
\text { Ernakulam, Idukki, Kollam, } \\
\text { Kottayam, Kozikode, } \\
\text { Lunglel, Malappuram, } \\
\text { Nilgiri, Thrissur, West Khasi } \\
\text { Hills }\end{array}$ & $\begin{array}{l}\text { Ajmer, Akola, Bahraich, Ballia, Barmer, Barpeta, Bastar, Basti, Bhagalpur, Bhojpur, Bikaner, Churu, Damoh, Darrang, Deoria, East Districts, } \\
\text { Etah, Etawah, Frozabad, Gonda, Jaisalmer, Jalor, Jodhpur, Kodagu, Kurnool, Lahul and Spiti, Lalitpur, Maharajganj, Maldah, Mandla, Nawada, } \\
\text { Nellore, North District, North Tripura, Pali, Pathanamchitta, Purnia, Rajgarh, Ralsen, Ramanathapuram, Sahibganj, Salem, Sawai Madhopur, } \\
\text { Sehore, Seoni, Shajapur, Siddharthnagar, Sitamarhi, South Districts, Sultanpur, Sundargarh, Ukhrul, Vidisha, West Nimar, West Tripura }\end{array}$ \\
\hline $\begin{array}{l}\text { The } \\
\text { average } \\
\text { GB } \\
\text { lower in } \\
2001\end{array}$ & $\begin{array}{l}\text { Ahmadabad, Aizam, Amreli, } \\
\text { Chandel, East Khasi Hills, } \\
\text { Gandhinagar, Hamirpur, } \\
\text { Hoshiarpur, Imphal, Imphal, } \\
\text { Jaintia Hills, Jalandhar, } \\
\text { Kangra, Kannur, } \\
\text { Kapurthala, Kasaragod, } \\
\text { Ludhiana, Madras, } \\
\text { Mokokchung, Mon, } \\
\text { Palakkad, Rajkot, Surat, } \\
\text { Thiruvananthapuram, } \\
\text { Valsad, Wardha, Wayanad, } \\
\text { Wokha, Zunheboto }\end{array}$ & 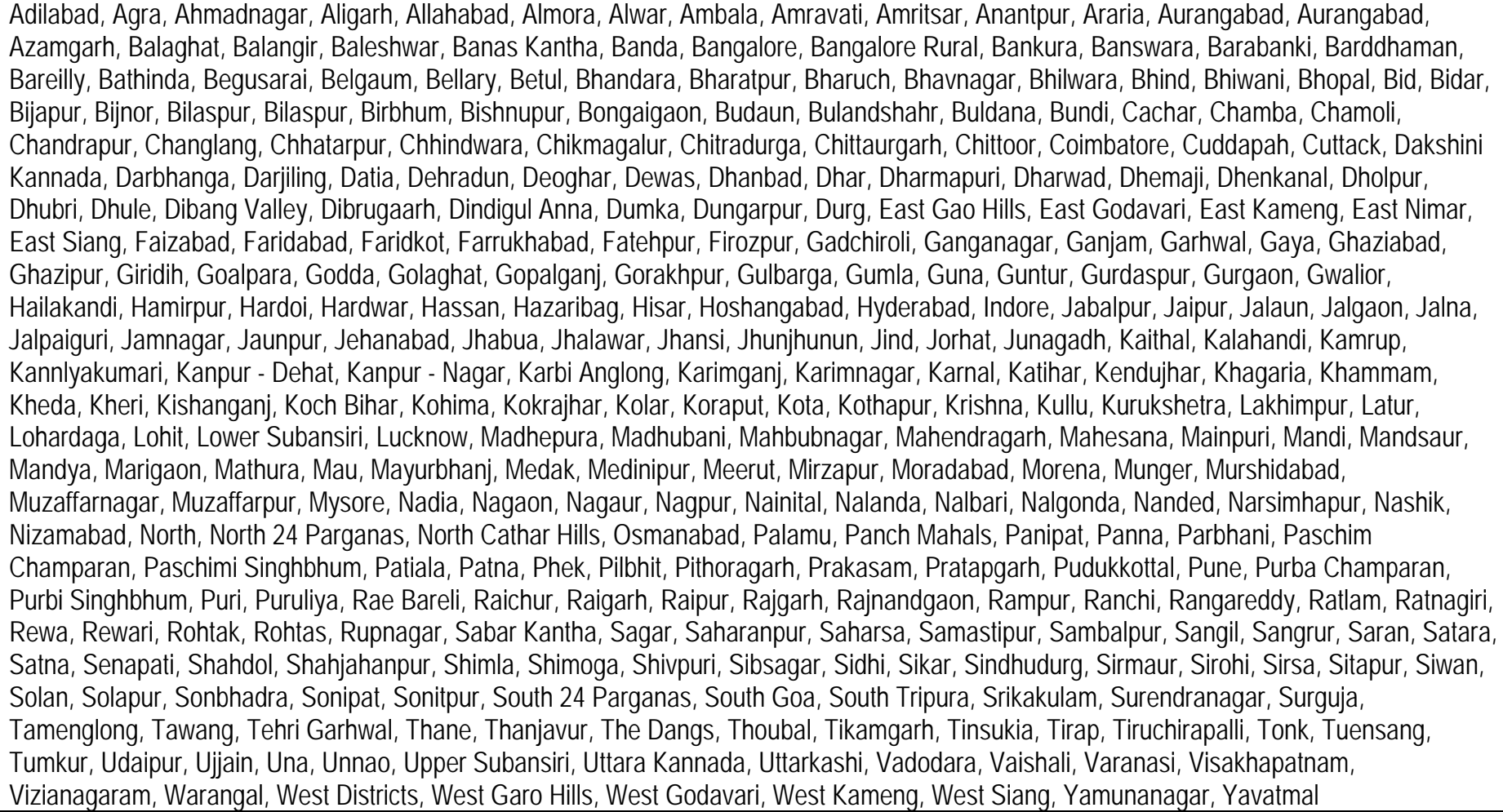 \\
\hline
\end{tabular}

Source: Calculated from India Census 1991, 2001 